Taras Gerya $\cdot$ Bernhard Stöckhert

\title{
Two-dimensional numerical modeling of tectonic and metamorphic histories at active continental margins
}

Received: 25 May 2004 / Accepted: 10 March 2005/ Published online: 27 September 2005

(C) Springer-Verlag 2005

\begin{abstract}
The evolution of an active continental margin is simulated in two dimensions, using a finite difference thermomechanical code with half-staggered grid and marker-in-cell technique. The effect of mechanical properties, changing as a function of $P$ and $T$, assigned to different crustal layers and mantle materials in the simple starting structure is discussed for a set of numerical models. For each model, representative $P-T$ paths are displayed for selected markers. Both the intensity of subduction erosion and the size of the frontal accretionary wedge are strongly dependent on the rheology chosen for the overriding continental crust. Tectonically eroded upper and lower continental crust is carried down to form a broad orogenic wedge, intermingling with detached oceanic crust and sediments from the subducted plate and hydrated mantle material from the overriding plate. A small portion of the continental crust and trench sediments is carried further down into a narrow subduction channel, intermingling with oceanic crust and hydrated mantle material, and to some extent extruded to the rear of the orogenic wedge underplating the overriding continental crust. The exhumation rates for (ultra)high pressure rocks can exceed subduction and burial rates by a factor of $1.5-3$, when forced return flow in the hanging wall portion of the self-organizing subduction channel is focused. The simulations suggest that a minimum rate of subduction is required for the formation of a subduction channel, because buoyancy forces may outweigh drag forces for slow subduction. For a weak upper continental crust, simulated by a high pore
\end{abstract}

T. Gerya $(\bowtie)$

Geologisches Institut, ETH - Zürich, 8092 Zurich, Switzerland

E-mail: taras.gerya@erdw.ethz.ch

T. Gerya

Institute of Experimental Mineralogy, Chernogolovka, Moscow District, Russia

B. Stöckhert

Institute of Geology, Mineralogy, and Geophysics,

Ruhr-University, Sonderforschungsbereich 526,

Bochum, Germany pressure coefficient in the brittle regime, the orogenic wedge and megascale melange reach a mid- to uppercrustal position within 10-20 Myr (after 400-600 km of subduction). For a strong upper crust, a continental lid persists over the entire time span covered by the simulation. The structural pattern is similar in all cases, with four zones from trench toward arc: (a) an accretionary complex of low-grade metamorphic sedimentary material; (b) a wedge of mainly continental crust, with medium-grade HP metamorphic overprint, wound up and stretched in a marble cake fashion to appear as nappes with alternating upper and lower crustal provenance, and minor oceanic or hydrated mantle interleaved material; (c) a megascale melange composed of high-pressure and ultrahigh-pressure metamorphic oceanic and continental crust, and hydrated mantle, all extruded from the subduction channel; (d) zone represents the upward tilted frontal part of the remaining upper plate lid in the case of a weak upper crust. The shape of the $P-T$ paths and the time scales correspond to those typically recorded in orogenic belts. Comparison of the numerical results with the European Alps reveals some similarities in their gross structural and metamorphic pattern exposed after collision. A similar structure may be developed at depth beneath the forearc of the Andes, where the importance of subduction erosion is well documented, and where a strong upper crust forms a stable lid.

Keywords Numerical experiment - Rheology · Subduction erosion - Subduction channel - Active continental margin $\cdot$ Orogenic belt $\cdot$ Metamorphic nappes $\cdot$ UHP metamorphism $\cdot$ Exhumation

\section{Introduction}

Studies of high-pressure (HP) and ultrahigh-pressure (UHP) metamorphic rocks exposed in collisional belts have shown that these units (1) are derived from both continental and oceanic crust intermingled on the length scale of nappes, (2) are frequently associated with hy- 
drated peridotites, (3) reveal a variable $P-T-t$ record, with (4) narrow time constraints indicating that exhumation rates can be on the order of plate velocity. Their (micro)structural record indicates that the deformation inherent in their burial and exhumation must have been highly localized in low-viscosity shear zones, for which some kind of dissolution precipitation creep or fluidassisted granular flow and Newtonian behavior is anticipated (Stöckhert 2002). The $P-T$ paths, the restricted size of the UHP metamorphic slices (e.g., Chopin 2003), and the narrow time constraints favor tectonic models that involve exhumation by forced flow in a subduction channel. Here we have extended our previous model of a subduction channel in the case of intraoceanic subduction (Gerya et al. 2002) to an active continental margin, driven by the following motivation.

It seems to be tacitly assumed by many authors (e.g., Hacker and Liou 1998; Chopin 2003) that UHP metamorphic continental crust is derived from the downgoing plate and thus generally indicates collision. Deep burial during collision is accordingly simulated in analog (e.g., Chemenda et al. 1995) and numerical studies (e.g., Burov et al. 2001). On the other hand, geochronology suggests that UHP metamorphism may have taken place prior to collision (e.g., Eide and Liou 2000). Furthermore, the limited size of UHP metamorphic slices, e.g., in the Alps, and the overall crustal volume available in orogenic belts bearing UHP metamorphic rocks does not support the hypothesis of burial and exhumation of coherent continental crust. Also, the volumetric problems inherent in the palinspastic reconstruction of the Alps, with individual microcontinents separated by oceanic branches, has been lucidly portrayed by Polino et al. (1990). On the other hand, subduction erosion is known to be an important process affecting the overriding continental crust at active continental margins (von Huene and Scholl 1991).

Here we present the results of a set of numerical simulations exploring how the chosen rheological properties and related mechanical behavior of the crust, the rate of mantle hydration, and the velocity of plate convergence influence the kinematic pattern, metamorphic history, and resultant structure in pre-collisional active continental margins. Independent of the chosen parameters, the simulations yield similar patterns and thus support a hypothesis alternative to collision for the source and history of (U)HP metamorphic continental crust. This hypothesis accounts for (U)HP metamorphism prior to collision, limited size of (U)HP metamorphic units, and the problem of storage of a large volume of continental crust inherent in accretion of microcontinents.

\section{Design of the models}

Initial configuration and concept of the simulation

For the present simulation of an active continental margin we used a two-dimensional (2-D) numerical model with a kinematically prescribed subducting plate and a simple model for the progressive hydration of the mantle wedge (Fig. 1) based on our previous studies (Gerya et al. 2002; Gerya and Yuen 2003a). The boundary conditions correspond to a corner flow model and account for asthenospheric mantle flow under the overriding plate. The initial position of the subduction zone is prescribed by a weak $5 \mathrm{~km}$ thick hydrated peridotite layer (Fig. 1a). During progressive subduction, this layer becomes substituted by subducted weak crustal rocks and hydrated mantle material, maintaining decoupling along the plate interface. The top surface (Fig. 1a) is calculated dynamically as a free surface using a $6-11 \mathrm{~km}$ thick top layer with a very low viscosity $\left(10^{18} \mathrm{~Pa} \mathrm{~s}\right)$ and density, simulating both the ambient atmosphere $\left(1 \mathrm{~kg} / \mathrm{m}^{3}\right.$, above $z=7.5 \mathrm{~km}$ level $)$ and sea water $\left(1,000 \mathrm{~kg} / \mathrm{m}^{3}\right.$, below $z=7.5 \mathrm{~km}$ level). The interface between this layer and the top of the oceanic/continental crust is treated as an erosion/sedimentation surface, which evolves according to the transport equation solved at each time-step (Gerya and Yuen 2003a):

$\partial z_{\mathrm{es}} / \partial t=v_{z}-v_{x} \partial z_{\mathrm{es}} / \partial x-v_{\mathrm{s}}+v_{\mathrm{e}}$

where $z_{\mathrm{es}}$ is the vertical position of the surface (from the top of the model, downward) as a function of the horizontal distance $x ; v_{z}$ and $v_{x}$ are the vertical and horizontal components of the material velocity vector at the surface; $v_{\mathrm{s}}$ and $v_{\mathrm{e}}$ are sedimentation and erosion rates, respectively, which correspond to the relation:

$$
\begin{gathered}
v_{\mathrm{s}}=0 \mathrm{~mm} / \mathrm{a}, \quad v_{\mathrm{e}}=v_{\mathrm{e} 0} \quad \text { when } z_{\mathrm{es}}<7.5 \mathrm{~km} \\
v_{\mathrm{s}}=v_{\mathrm{s} 0} \mathrm{~mm} / \mathrm{a}, \quad v_{\mathrm{e}}=0 \quad \text { when } z_{\mathrm{es}}>7.5 \mathrm{~km}
\end{gathered}
$$

where $v_{\mathrm{e} 0}$ and $v_{\mathrm{s} 0}$ are imposed constant erosion and sedimentation rates, respectively. There is a slight feedback between topographical variations and displacement in the underlying crust, which is related to changes in the dynamic horizontal pressure gradients (e.g., Poliakov et al. 1993; Ellis et al. 2001).

\section{Progressive hydration of the mantle wedge}

To account for the effects of the process of hydration (Fig. 1d) in a viscous medium, we describe the vertical displacement of the hydration front (i.e., the interface between hydrated and dry mantle rock) with respect to the upper surface of the subducting slab by the following transport equation (Gerya et al. 2002) solved at each time-step

$\partial z_{\mathrm{h}} / \partial t=v_{z}-v_{x} \partial z_{\mathrm{h}} / \partial x-v_{\mathrm{h}}$

where $z_{\mathrm{h}}$ is the vertical location of the hydration front as a function of the horizontal distance, $x$, measured from the trench; $v_{\mathrm{h}}$ is the hydration rate; $v_{z}$ and $v_{x}$ are the vertical and horizontal components of the material velocity vector at the front.

The availability of water controls the progress of mantle hydration (e.g., Peacock 1987). We assume, 

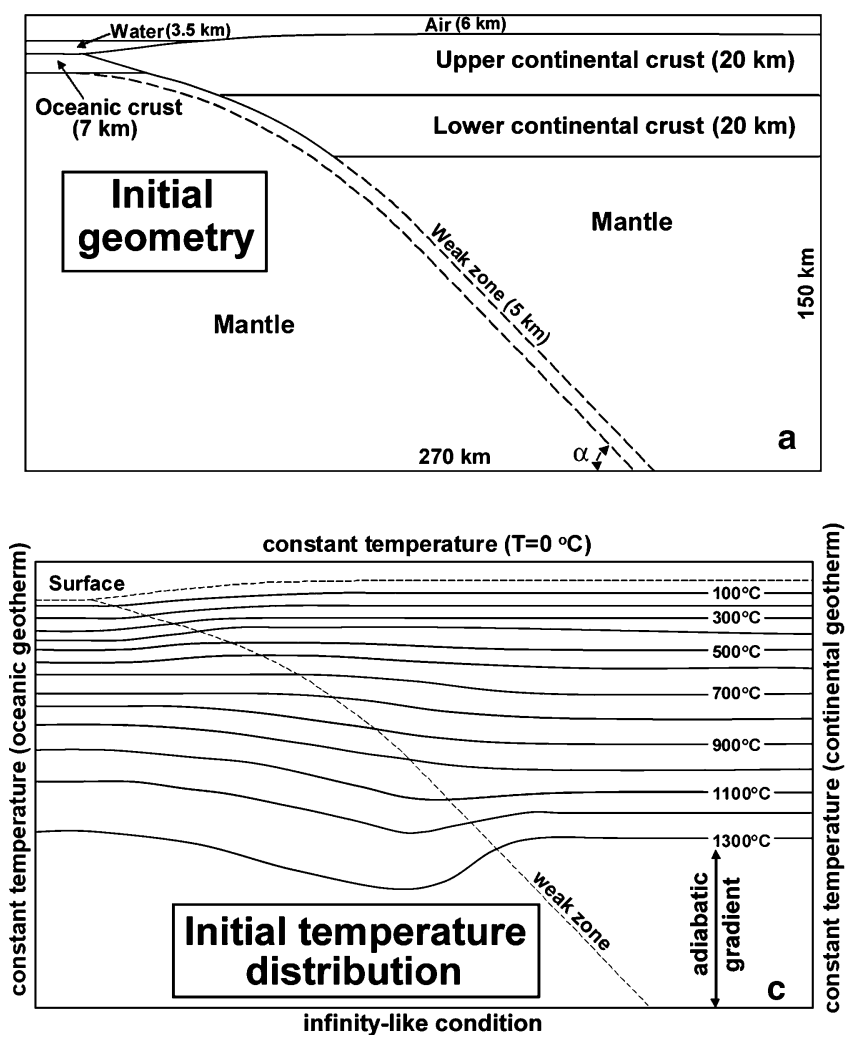

Fig. 1 Initial configuration, starting and boundary conditions of our numerical simulation of an active continental margin. The computational domain is regional in character, and kinematic boundary conditions are imposed. The initial temperature field in the subducting plate, with a given uniform descending rate, is defined by an oceanic geotherm $T_{0}(z)$ with a specified age. Initial temperature distribution in the overriding plate $T_{1}(z)$ corresponds to the equilibrium thermal profile with $0^{\circ} \mathrm{C}$ at the surface and $1,350^{\circ} \mathrm{C}$ at $90 \mathrm{~km}$ depth. The thermal boundary condition $\partial^{2} \mathrm{~T} /$

therefore, that spatial changes in the hydration rate along the hydration front should mainly depend on spatial changes in the rate of fluid release along the surface of the subducting plate. Assuming a continuous (Schmidt and Poli 1998) dehydration of the subducting slab, we also account for the vertical displacement of the hydration front (Fig. 1) in the deforming mantle wedge with respect to the upper interface of the subducting slab. The hydration leads to a sharp decrease in density and viscosity of the mantle rocks, creating favorable conditions for corner flow in a wedge-shaped subduction channel. The hydration rate, $v_{\mathrm{h}}$, is approximated (Gerya et al. 2002) by a linear function of the horizontal distance, $x$, measured from the trench (Fig. 1):

$$
\begin{gathered}
v_{\mathrm{h}} / v_{\mathrm{s}}=A\left[1-B x / x_{\lim }\right] \quad \text { when } x<x_{\lim } \\
v_{\mathrm{h}} / v_{\mathrm{s}}=0 \quad \text { when } x>x_{\lim }
\end{gathered}
$$

where

$v_{\mathrm{s}}$ is the subduction rate; $x_{\lim }$ is the limiting horizontal distance from the trench to the right of which fluid release from the subducting plate is negligible (Gerya et al. 2002). The non-dimensional parameter $B$ may vary from -1 to 1 , characterizing either the increase
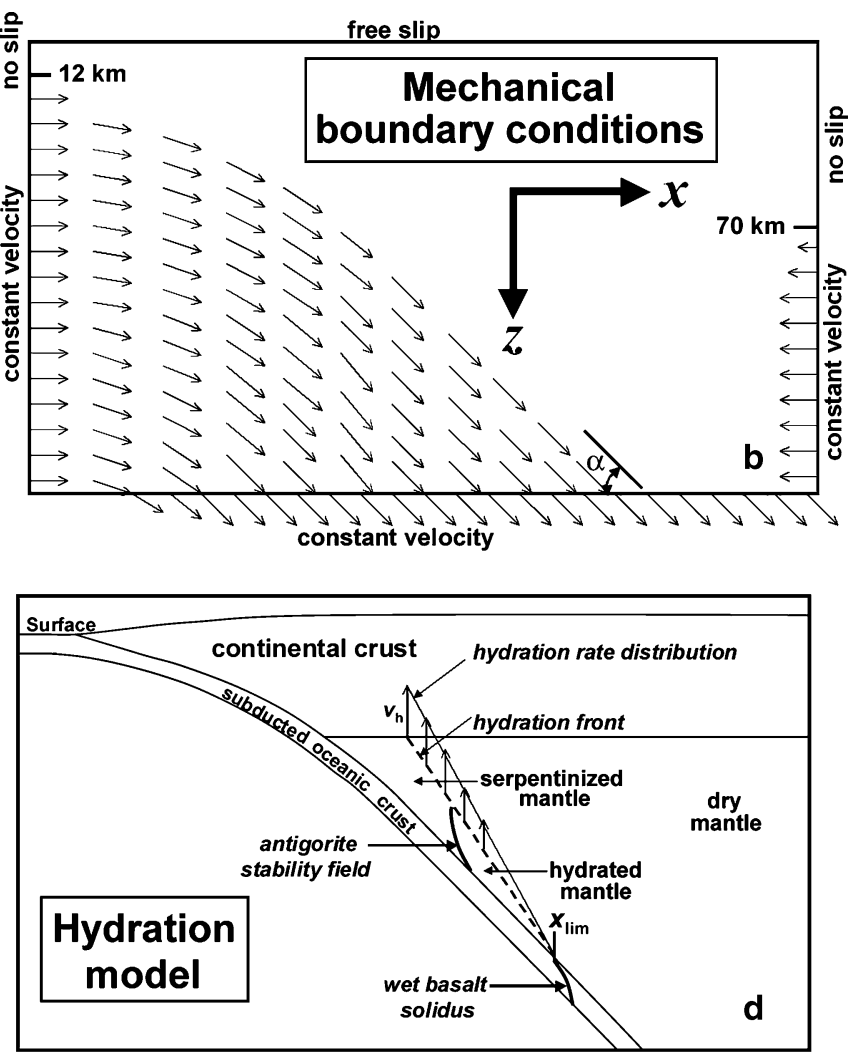

$\partial z^{2}=0$ simulating continuity of the temperature field in a vertical direction is used along the lower boundary (Gerya et al. 2002). The initial structure of the $7 \mathrm{~km}$ thick oceanic crust is taken as follows (top to bottom): upper oceanic crust $=3 \mathrm{~km}$ (sedimentary and basaltic rocks), lower oceanic crust $=4 \mathrm{~km}$ (gabbroic rocks). The initial thickness of the continental crust $=40 \mathrm{~km}$. The hydration rate, $v_{\mathrm{h}}$, is approximated by a linear function depending on the horizontal distance, $x$, measured from the trench

$(B<0)$ or the decrease $(B>0)$ in hydration rate with depth. The parameter $A$ is a non-dimensional intensity in the process of hydration of the mantle wedge. Typical values of the parameter $A$ range between 0.01 and 0.30 as a function of (1) the water contents in the hydrated peridotite and (2) the total amount of water released from the subducting plate by the limiting distance $x_{\text {lim }}$ (Gerya et al. 2002).

\section{Rock rheology: general concepts}

For crust and mantle materials we have employed a composite viscous rheology, which encompasses the variability of the lithological phases (Table 1), temperature, and strain rate. The effective dislocation creep viscosity of rocks depending on stress and temperature is defined in terms of deformation invariants (Ranalli 1995)

$\eta_{\text {disl }}=\left(\dot{\varepsilon}_{\text {II }}\right)^{(1-n) / 2 n} F\left(A_{\mathrm{D}}\right)^{-1 / n} \exp (E / n R T)$

where $\dot{\varepsilon}_{\mathrm{II}}=12 \dot{\varepsilon}_{i j} \dot{\varepsilon}_{i j}$ is the second invariant of the strain rate tensor, with dimension $\mathrm{s}^{-2} ; A_{\mathrm{D}}, E$, and $n$ are 
Table 1 Material properties ${ }^{\mathrm{a}}$ used in 2-D numerical experiments

\begin{tabular}{|c|c|c|c|c|}
\hline Material & $\rho_{0}\left(\mathrm{~kg} / \mathrm{m}^{3}\right)$ & $\begin{array}{l}\text { Thermal } \\
\text { conductivity } \\
(\mathrm{W} / \mathrm{m} / \mathrm{K})\end{array}$ & Rheology & $H_{\mathrm{r}}\left(\mu \mathrm{W} / \mathrm{m}^{3}\right)$ \\
\hline Sedimentary rocks & 2,700 & $0.64+\frac{807}{T+27}$ & Wet quartzite flow law, $\lambda=0.90$ & 2 \\
\hline Upper continental crust & 2,700 & $0.64+\frac{807^{7}}{T+27}$ & Wet quartzite flow law & 1 \\
\hline Lower continental crust & 2,700 & $0.64+\frac{18077}{T+77}$ & Wet quartzite flow law & 0.5 \\
\hline Upper oceanic crust & 3,100 & $1.18+\frac{474}{T+77}$ & $\begin{array}{l}\text { Constant viscosity } 10^{19} \mathrm{~Pa} \mathrm{~s} \text {, } \\
\text { wet quartzite flow law }\end{array}$ & 0.25 \\
\hline Lower oceanic crust & 3,100 & $1.18+\frac{474}{T+77}$ & Diabase flow law & 0.25 \\
\hline Serpentinized mantle & 3,000 & $0.73+\frac{1,293}{T+77}$ & Constant viscosity $10^{19} \mathrm{~Pa} \mathrm{~s}, \lambda_{10}=0.90$ & 0.022 \\
\hline $\begin{array}{l}\text { Hydrated mantle beyond } \\
\text { the serpentine stability field }\end{array}$ & 3,300 & $0.73+\frac{1,293}{T+77}$ & Wet olivine flow law, $\lambda_{10}=0.90$ & 0.022 \\
\hline Dry mantle & 3,300 & $0.73+\frac{1,293}{T+77}$ & Dry olivine flow law, $\lambda_{10}=0$ & 0.022 \\
\hline References & $\begin{array}{l}\text { Turcotte and } \\
\text { Schubert (1982) }\end{array}$ & $\begin{array}{l}\text { Clauser and } \\
\text { Huenges (1995) }\end{array}$ & $\begin{array}{l}\text { Chopra and Paterson (1981), } \\
\text { Ranalli (1995), } \\
\text { Mackwell et al. (1998), } \\
\text { Gerya et al. (2002) }\end{array}$ & $\begin{array}{l}\text { Turcotte and } \\
\text { Schubert (1982) }\end{array}$ \\
\hline
\end{tabular}

${ }^{\mathrm{a}} C_{p}=1,000 \mathrm{~J} / \mathrm{kg}, \alpha=3 \times 10^{-5} \mathrm{~K}^{-1}, \beta=1 \times 10^{-5} \mathrm{Mpa}^{-1}$ for all types of rocks

${ }^{\mathrm{b}}$ The serpentine stability field (Schmidt and Poli 1998): $T>751+0.18 P-0.000031 P^{2}$ at $P<2,100 \mathrm{MPa}$,

$T>1,013-0.0018 P-0.0000039 P^{2}$ at $P>2,100 \mathrm{MPa}$

experimentally determined flow law parameters (Ranalli 1995). $F$ is a dimensionless coefficient depending on the type of experiments on which the flow law is based (e.g., $F=2^{(1-n) / n} / 3^{(1+n) / 2 n}$ for triaxial compression and $F=2^{(1-2 n) / n}$ for simple shear).

At low deviatoric stresses thermally activated diffusion creep should dominate in deforming rocks. Following Turcotte and Schubert (1982) we assume a transition from dislocation to diffusion creep at a given value of transition deviatoric stress, $\sigma_{\text {tr }}$, independent of temperature that implies

$\eta_{\text {diff }}=\left(12 \sigma_{\text {tr }}\right) /\left(\dot{\varepsilon}_{\text {IItr }}\right)^{1 / 2}$

where $\dot{\varepsilon}_{\text {IItr }}$ is the transitional value of the second strain rate invariant calculated from Eq. 4 and the standard relation $\left(12 \sigma_{\text {tr }}\right)=\left(\dot{\varepsilon}_{\text {IItr }}\right)^{1 / 2} \eta_{\text {disl }}$. The effective viscosity of a rock deforming by diffusion creep, depending on temperature, is then defined by

$\eta_{\text {diff }}=\left(A_{\mathrm{D}}\right)^{-1}\left(\frac{1}{2} \sigma_{\mathrm{tr}}\right)^{1-n} F^{n} \exp (E / R T)$

We adopted a low transition stress value $\left(\sigma_{\mathrm{tr}}=0.03 \mathrm{MPa}\right)$ for dry mantle rocks (e.g., Turcotte and Schubert 1982), which is therefore mainly deformed in the dislocation creep regime. For crustal rocks and hydrated mantle we explored the effect of significant variations of this parameter $\left(\sigma_{\mathrm{tr}}=0.03-30 \mathrm{MPa}\right)$ in order to test how the models respond to different creep regimes in crustal rocks (Table 2).

The strength of solid rocks in the brittle field is implemented as a limiting maximum viscosity

$\eta_{\max }=\left(\frac{1}{2} \sigma_{\text {yield }}\right) /\left(\dot{\varepsilon}_{\text {II }}\right)^{1 / 2}$

where $\sigma_{\text {yield }}=\left(N_{1} P_{\text {lith }}+N_{2}\right)(1-\lambda)$ is the yield stress; $P_{\text {lith }}$ is the lithostatic depth-dependent pressure, $\mathrm{MPa} ; N_{1}$ and
$N_{2} \quad(\mathrm{MPa})$ are empirical constants: $N_{1}=0.85$, $N_{2}=0<\sigma_{\text {yield }}<200 \mathrm{MPa}$ and $N_{1}=0.6, N_{2}=60$ when $\sigma_{\text {yield }}>200 \mathrm{MPa}$ (Brace and Kohlestedt 1980); $\lambda$ is the pore fluid pressure coefficient (Table. 1, 2). Our model for the brittle field bounds the overall strength of the brittle upper layer of the continental crust. Despite being simplistic and not allowing simulating localized deformation in fault zones, it is supposed to serve well for the present purpose.

Finally, an effective creep viscosity $\eta$ is calculated according to the formula given below (e.g., Schott and Schmeling 1998) providing smooth transitions between different regimes of deformation

$1 / \eta=1 / \eta_{\text {disl }}+1 / \eta_{\text {diff }}+1 / \eta_{\max }$

Rock rheology: choice of flow laws and assumptions for different materials

The mechanical equations of state assigned to different materials in the simulations need to represent the bulk behavior of the crust or mantle on the respective length scales. The problems inherent in the extrapolation of experimental flow laws to natural length and time scales were discussed, e.g., by Paterson (1987). Shortcomings in crustal scale simulations arise from the localization of deformation commonly observed in natural rocks on length scales below the resolution of the numerical simulation. Also, the general heterogeneity of the crust on all length scales cannot be accounted for in the simulation. Finally, it must be borne in mind that flow laws for single phase materials do not adequately describe properties of polyphase materials. The choice of flow laws is, therefore, to some extent ambiguous. Probably the assignment of Newtonian vs power law creep is the most important aspect, as this has a signif- 


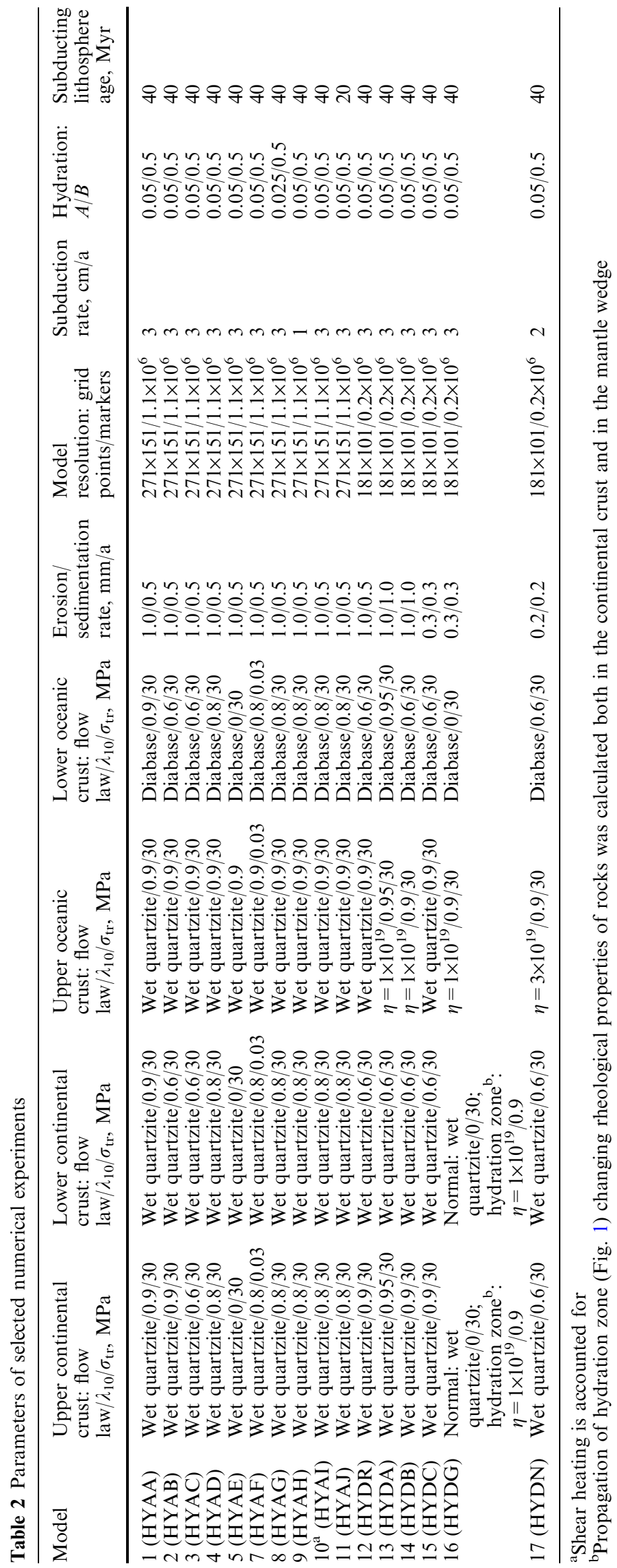


icant influence on the behavior of the subduction channel (Gerya and Stöckhert 2002). Our basic concept of subduction zone rheology is based on the following considerations.

High-pressure metamorphic rocks exhumed from subduction zones reveal little evidence of deformation of their predominating minerals at depth by dislocation creep (Stöckhert and Renner 1998; Mauler et al. 2001; Stöckhert 2002). Moreover, many HP and UHP metamorphic rocks have remained nearly undeformed (Biino and Compagnoni 1992; Liou and Zhang 1997; Renner et al. 2001; Oberhänsli et al. 2002; Stöckhert 2002). This requires that deformation during subduction and exhumation be localized into weak shear zones. Dissolution precipitation creep and fluid-assisted granular flow are expected to be the dominant deformation mechanisms in these shear zones and a Newtonian behavior is suggested. With an assumption on the cumulative width of the shear zones, typical plate velocities, and an upper bound to stress provided by the flow laws for dislocation creep of rock-forming minerals such as quartz and coesite (Renner et al. 2001; Stöckhert 2002), maximum bulk viscosities on the order of $10^{18}-10^{19} \mathrm{~Pa} s$ are predicted for the materials in the subduction channel.

Accordingly, a Newtonian rheology of subducted oceanic crust and serpentinized mantle (Fig. 1d) is implemented by using a constant effective viscosity $\eta_{\text {creep, }}$, with an absolute value of $10^{19} \mathrm{~Pa}$ s. This simplification is based on the assumption that deformation takes place by grain size and temperature-dependent diffusion creep. Using an empirical dependence of grain size on temperature, Gerya et al. (2002) have argued that for an activation energy of $(150 \mathrm{~kJ} / \mathrm{mol}$ the effect of temperature may be balanced by increasing grain size, giving rise to a uniform viscosity independent of temperature between 300 and $700^{\circ} \mathrm{C}$.

\section{Brittle upper crust}

The pore fluid pressure controls the brittle strength of fluid containing porous or fractured media. A hydrostatic gradient with a pore pressure coefficient $\lambda=0.4$ is generally accepted for the upper crust (e.g., Sibson 1990). Hydrocarbon exploration wells have shown that in sedimentary basins the transition from a hydrostatic to a near-lithostatic pore pressure gradient generally occurs at about 3-5 km depth (e.g., Sibson 1990). In contrast, the KTB drillhole has shown that in metamorphic basement rocks a hydrostatic pore pressure gradient can reach down to at least $9 \mathrm{~km}$ depth and a temperature of $265^{\circ} \mathrm{C}$ (Grawinkel and Stöckhert 1997; Huenges et al. 1997). For simplicity, we assumed a continuous transition from the hydrostatic pore fluid pressure $(\lambda=0.4)$ at the surface to a characteristic pore fluid pressure $\left(\lambda_{10}=0-0.9\right)$ at $10 \mathrm{~km}$ depth. Intermediate pore fluid pressures are thus assumed at shallow depths
$<10 \mathrm{~km}$, with an effective pore fluid pressure calculated as follows (Gerya et al. 2002):

$\lambda=\left[0.4\left(10,000-\Delta z_{\mathrm{es}}\right)+\lambda_{10} \Delta z_{\mathrm{es}}\right] / 10,000$

where $\lambda_{10}$ is a pore fluid pressure coefficient at a depth $>10 \mathrm{~km}$ for a given type of material (Table. 1,2) and $\Delta z_{\text {es }}$ is the depth below the calculated dynamic erosion/ sedimentation surface, $\mathrm{m}$.

\section{Upper continental and lower continental crust, accreted and subducted sediments}

Beneath the brittle-ductile transition the rheology of upper and lower continental crust, and of accreted or subducted sediments, is simulated using a power law for wet quartzite, with $E=135 \mathrm{~kJ} / \mathrm{mol}, \quad n=3.1$, and $\log A_{\mathrm{D}}=-7.2\left(A_{\mathrm{D}}\right.$ given in $\left.\mathrm{MPa}^{-n} \mathrm{~s}^{-1}\right)$, as quoted by Paterson and Luan (1990). This simplification is assumed to represent an acceptable compromise bearing in mind the extreme compositional heterogeneity of the continental crust, the uncertainty about deformation mechanisms in polyphase materials, and the likelihood of strain localization in shear zones, which cannot be dealt with in the simulations.

\section{Upper oceanic crust}

Upper basaltic oceanic crust is generally strongly affected by hydrothermal alteration at mid-ocean ridges. With increasing age, it becomes covered by oceanic sediments, typically siliceous oozes (cherts) when deposited beneath the carbonate compensation depth. Upon subduction, the hydrated basaltic material is metamorphosed to greenschists, blueschists, and eclogites. The cherts become quartzites, and sediments comprising some clay minerals are transformed into phyllites and micaschists. The microstructural record of respective natural rocks exhumed from subduction channels suggests that deformation is mainly by dissolution precipitation creep, with dislocation creep restricted to pure quartz rocks (Stöckhert et al. 1999; Stöckhert 2002). For subducted upper oceanic crust, we therefore use either a constant viscosity of $10^{19} \mathrm{~Pa} \mathrm{~s}$ or, alternatively, a power law rheology for wet quartzite (Paterson and Luan 1990), with a switch to a Newtonian rheology below a specified transition stress level ( $\sigma_{\mathrm{tr}}$, Eq. 5).

\section{Lower oceanic crust}

Compared to the upper basaltic-sedimentary layer, the lower gabbroic oceanic crust is assumed to be little affected by hydrothermal circulation at mid-ocean ridges. Therefore, a power law rheology is used for the lower gabbroic portion of the oceanic crust, represented by a flow law for dislocation creep of diabase, with 
$E=485 \mathrm{~kJ} / \mathrm{mol}, n=4.7$, and $\log A_{\mathrm{D}}=2.3\left(A_{\mathrm{D}}\right.$ given in $\mathrm{MPa}^{-n} \mathrm{~s}^{-1}$ ), as quoted by Mackwell et al. (1998).

\section{Unserpentinized mantle}

Olivine rheology is constrained by laboratory tests (e.g., Chopra and Paterson 1981; Mei and Kohlstedt 2000), with a pronounced effect of chemical environment (e.g., Bai et al. 1991; Mei and Kohlstedt 2000). Here, the rheology of unhydrated mantle is represented by a flow law for dislocation creep of dry olivine, with $E=535 \mathrm{~kJ} /$ mol, $n=3.6$, and $\log A_{\mathrm{D}}=4.5\left(A_{\mathrm{D}}\right.$ given in $\left.\mathrm{MPa}^{-n} \mathrm{~s}^{-1}\right)$ (Chopra and Paterson 1981). Brittle strength is high, assuming the absence of a free pore fluid $\left(\lambda_{10}=0\right.$ in Eq. $8)$. The rheology of the partially hydrated mantle beyond the antigorite stability field (Fig. 1d) is represented by a flow law for dislocation creep of wet olivine, with $E=470 \mathrm{~kJ} / \mathrm{mol}, n=4$, and $\log A_{\mathrm{D}}=3.3$ ( $A_{\mathrm{D}}$ given in $\mathrm{MPa}^{-n} / \mathrm{s}^{-1}$ ) (Ranalli 1995), assuming a high pore fluid pressure $\left(\lambda_{10}=0.9\right.$ in Eq. 8$)$.

\section{Serpentinized mantle}

Serpentinized peridotite is generally assumed to be a very weak material (e.g., Guillot et al. 2000; Hermann et al. 2000), although the available laboratory experiments in the brittle field (e.g., Escartin and Hirth 1997; Moore et al. 1997; Escartin et al. 2001) are not appropriate to predict rheological properties of serpentinized or partly serpentinized mantle rocks at high pressure and temperature, and at slow geological strain rates in a mantle wedge. Here we use the antigorite stability field (Schmidt and Poli 1998) to define the boundary between a weak serpentinized mantle and a strong serpentine-free mantle. A Newtonian rheology with a constant viscosity of $10^{19} \mathrm{~Pa} \mathrm{~s}$, independent of temperature, is chosen to represent the mechanical behavior of the serpentinized mantle within the antigorite stability field (Fig. 1d).

\section{Numerical approach}

We have considered two-dimensional creeping flow taking thermal and chemical buoyancy forces into account. The conservation of mass is approximated by the incompressible continuity equation

$\partial v_{x} / \partial x+\partial v_{z} / \partial z=0$ form:

The 2-D Stokes equations for creeping flow take the

$\partial \sigma_{x x} / \partial x+\partial \sigma_{x z} / \partial z=\partial P / \partial x$

$\partial \sigma_{z z} / \partial z+\partial \sigma_{x z} / \partial x=\partial P / \partial z-g \rho(T, P, C)$

where the density $\rho(T, P, C)$ depends explicitly on temperature, pressure, and rock composition (C) according to the relation
$\rho(T, P, C)=\rho_{0}(C)\left[1-\alpha\left(T-T_{0}\right)\right] \times\left[1+\beta\left(P-P_{0}\right)\right]$

where $\rho_{0}(C)$ is the standard density at $P_{0}=0.1 \mathrm{MPa}$ and $T_{0}=298 \mathrm{~K}$, depending on rock composition (Table 1); $\alpha$ and $\beta$ are, respectively, the thermal expansion and compressibility coefficients.

Change in density due to phase transformations is probably much more important. However, at present, there seems to be no appropriate model to account for the widespread metastable preservation of mineral assemblages both in burial (e.g., Hacker 1996; Kirby et al. 1996) and exhumation, the latter being most obvious from the widespread occurrence of HP metamorphic rocks exposed at the surface. As the volumes affected by these phase transformations on the length scales addressed in our simulations, and the uncertainty in the degree of overstepping in both directions are unknown, change in density due to phase transformations is neglected in the models shown here.

We employ viscous rheological constitutive relationships between stress and strain rate, whose coefficient $\eta$ represents the effective viscosity, which depends on the composition, temperature, and strain rate

$\sigma_{x x}=2 \eta \dot{\varepsilon}_{x x}, \quad \sigma_{x z}=2 \eta \dot{\varepsilon}_{x z}, \quad \sigma_{z z}=2 \eta \dot{\varepsilon}_{z z}$

$\dot{\varepsilon}_{x x}=\partial v_{x} / \partial x, \quad \dot{\varepsilon}_{x z}=12\left(\partial v_{x} / \partial z+\partial v_{z} / \partial x\right), \quad \dot{\varepsilon}_{z z}=\partial v_{z} / \partial z$

We have adopted (Gerya and Yuen 2003b) a Lagrangian frame of reference in which the temperature equation with a temperature-dependent thermal conductivity $k(T)$ takes the form

$$
\begin{aligned}
& \rho C_{p}(\mathrm{D} T / \mathrm{D} t)=-\partial q_{x} / \partial x-\partial q_{z} / \partial z+H_{\mathrm{r}}+H_{\mathrm{s}} \\
& q_{x}=-k(T)(\partial T / \partial x), \quad q_{z}=-k(T)(\partial T / \partial z) \\
& H_{\mathrm{r}}=\mathrm{constant}, \quad H_{\mathrm{s}}=\sigma_{x x} \dot{\varepsilon}_{x x}+\sigma_{z z} \dot{\varepsilon}_{z z}+2 \sigma_{x z} \dot{\varepsilon}_{x z}
\end{aligned}
$$

where $\mathrm{D} / \mathrm{D} t$ represents the substantive time derivative.

Notations in Eqs. 9, 10, 11, 12, 13, and 14 are: $x$ and $z$ the horizontal and vertical coordinates, in $\mathrm{m}$, respectively; $v_{x}$ and $v_{z}$ are components of the velocity vector $\underline{v}$ in $\mathrm{m} / \mathrm{s} ; t$ time in $\mathrm{s} ; \sigma_{x x}, \sigma_{x z}, \sigma_{z z}$ are components of the viscous deviatoric stress tensor in $\mathrm{Pa} ; \dot{\varepsilon}_{x x} x x, \dot{\varepsilon}_{x z}, \dot{\varepsilon}_{z z}$ are components of the strain rate tensor in $\mathrm{s}^{-1} ; P$ the pressure in $\mathrm{Pa} ; T$ the temperature in $\mathrm{K} ; q_{x}$ and $q_{z}$ are heat fluxes in $\mathrm{W} / \mathrm{m}^{2} ; \eta$ the effective viscosity in Pa s; $\rho$ the density in $\mathrm{kg} / \mathrm{m}^{3} ; g=9.81 \mathrm{~m} / \mathrm{s}^{2}$ is the gravitational acceleration; $k$ is the thermal conductivity in $\mathrm{W} / \mathrm{m} / \mathrm{K} ; C_{p}$ is the isobaric heat capacity in $\mathrm{J} / \mathrm{kg} / \mathrm{K} ; H_{\mathrm{r}}$ and $H_{\mathrm{s}}$ denote, respectively, radioactive and shear heat production in $\mathrm{W} / \mathrm{m}^{3}$. Assuming decoupling at the plate interface due to hydration of the overriding plate we neglect shear heating in most of our numerical experiments (Table 2).

We use the 2-D code I2 based on finite-differences with a marker-in-cell technique, which allows for the accurate conservative solution of the governing equations on a rectangular half-staggered Eulerian grid for multiphase flow (Gerya et al. 2000; Gerya and Yuen 2003b). 

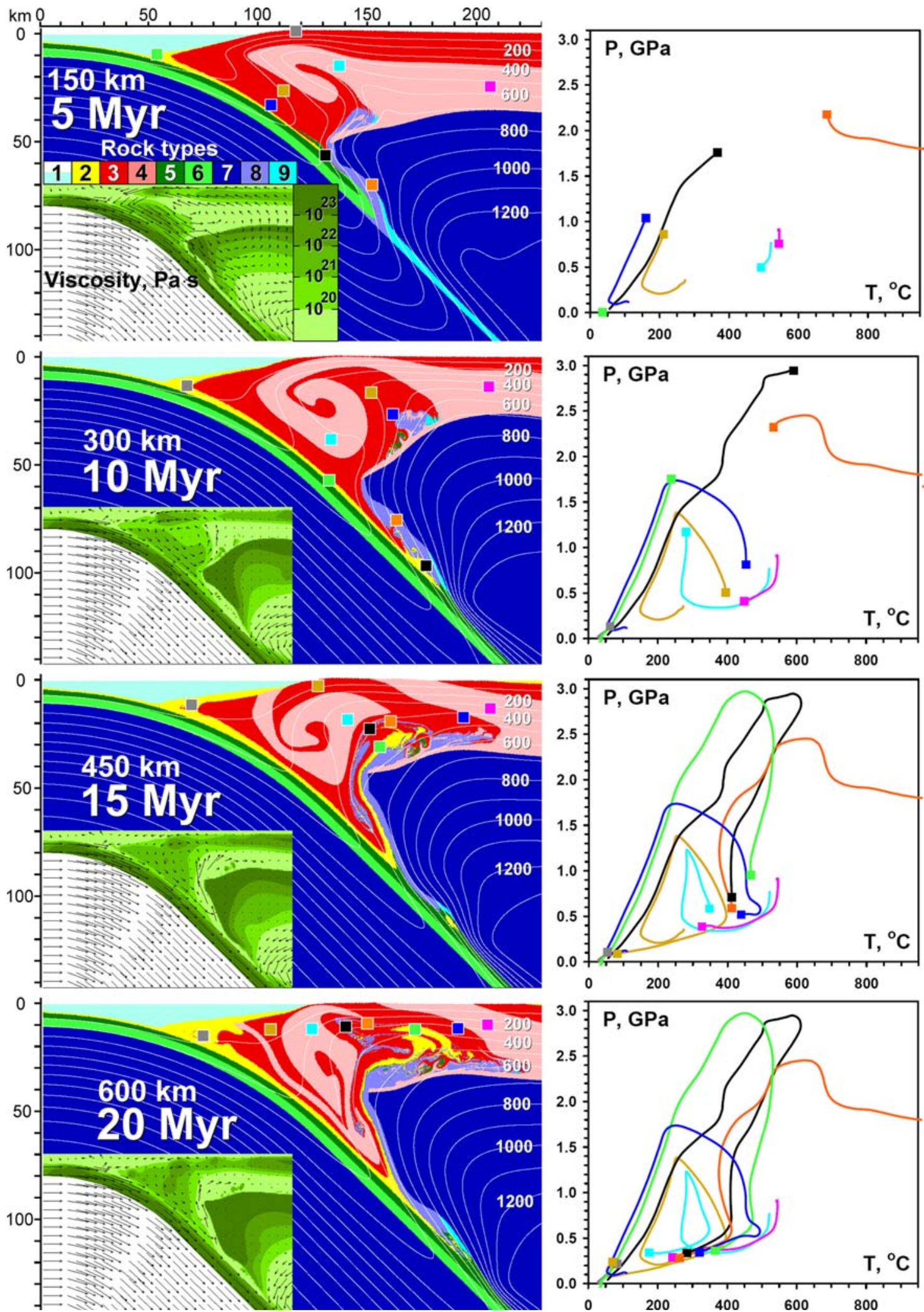

Fig. 2 Evolution of the reference model HYAD (model 4 in Table 2) of the active margin shown in four time slabs (5, 10, 15, and 20 Myr) corresponding to $150,300,450$, and $600 \mathrm{~km}$ of subduction. Rock types are as follows: 1 weak layer (air, sea water), 2 sediments, 3 upper continental crust, 4 lower continental crust, 5 upper oceanic crust, 5 lower oceanic crust, 7 dry mantle, 8 serpentinized mantle, 9 hydrated mantle beyond the stability field of antigorite. The colors of the squares refer to the diagram with the $P-T$ paths and do not correspond to rock types 
Fig. 3 Evolution of stress (left column) and stain rate (right column) distribution for the reference model HYAD shown in Fig. 2. Arrows in the right column show calculated velocity field. Crosses in the left column show orientation of principal stresses. Long and short axes denote directions of extension and compression, respectively

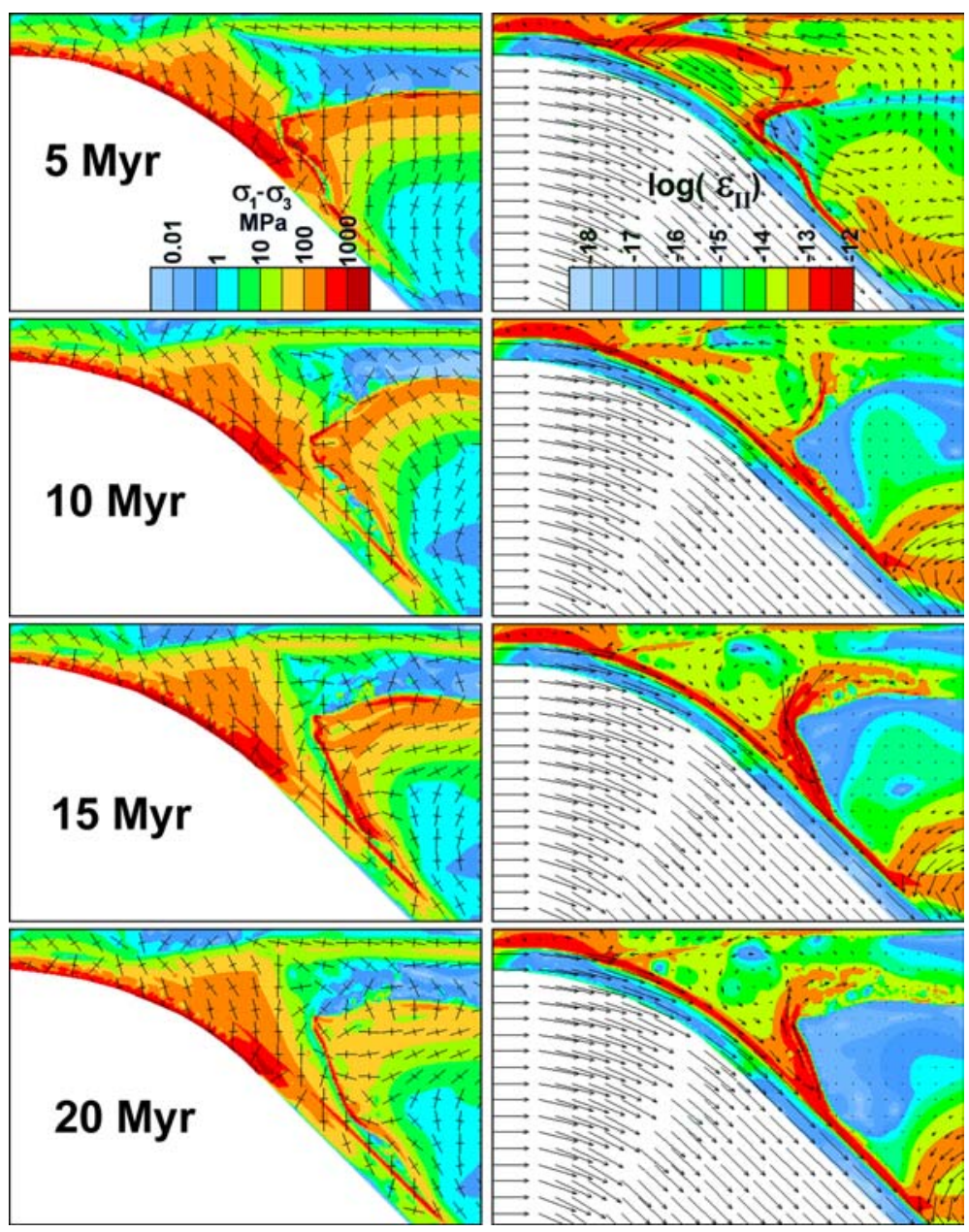

Altogether we have carried out 53 numerical runs over a $181 \times 101$ to $271 \times 151$ regular Eulerian grid with $0.2-1.1$ million markers for the detailed geometry representation. Details of 17 selected runs are given in Table 2. We also systematically studied the spatial trajectories and $P-T-t$ paths of various crustal and mantle rocks in order to allow a comparison with the natural record from HP and UHP metamorphic complexes. The effect of variations in erosion and sedimentation rates (Eq. 1) on structural and metamorphic evolution discussed below was explored (Table 2), but turned out to be relatively unimportant.

\section{Numerical modeling and visualization of the results}

The results of our six selected models are depicted in Figs. 2, 3, 4, 5, 6, 7, 8, and 9. After specification of the assumptions and input parameters, the characteristic features of the respective model are described. The first model HYAD is taken as the reference model, with the general pattern clearly developed, and the subsequent models with a differing input are compared to it.

\section{Reference model HYAD}

This numerical simulation (Model 4 in Table 2, Figs. 2, $3,9 a$ ) is characterized by a moderate subduction rate of $3 \mathrm{~cm} / \mathrm{a}$, a moderate brittle strength of the overriding continental crust $\left(\lambda_{10}=0.8\right)$, a moderate hydration rate $(A=0.05)$, and a high stress $\left(\sigma_{\mathrm{tr}}=30 \mathrm{MPa}\right)$ for the transition of dislocation to diffusion creep for all crustal rocks. The following important features are found for this model:

1. The accretionary complex is well developed. A backstop system forms due to the contrast in the brittle strength of sedimentary rocks $\left(\lambda_{10}=0.9\right)$ and the overriding continental crust $\left(\lambda_{10}=0.8\right)$.

2. A subduction channel reaches down to a depth of nearly $100 \mathrm{~km}$, with pronounced forced return flow of UHP rocks (see $P-T$ paths in Fig. 2, $20 \mathrm{Myr}$ ). Return flow and rapid exhumation are controlled by the relatively low flow stresses on the order of $10 \mathrm{MPa}$ (Fig. 4, 15, 16, 17, 18, 19, $20 \mathrm{Myr}$, left column) characteristic of the subducted crustal rocks deformed in the diffusion creep regime. A nearly planar zone with exhumed rocks penetrates into the crust and is bound by two zones with high strain rates 

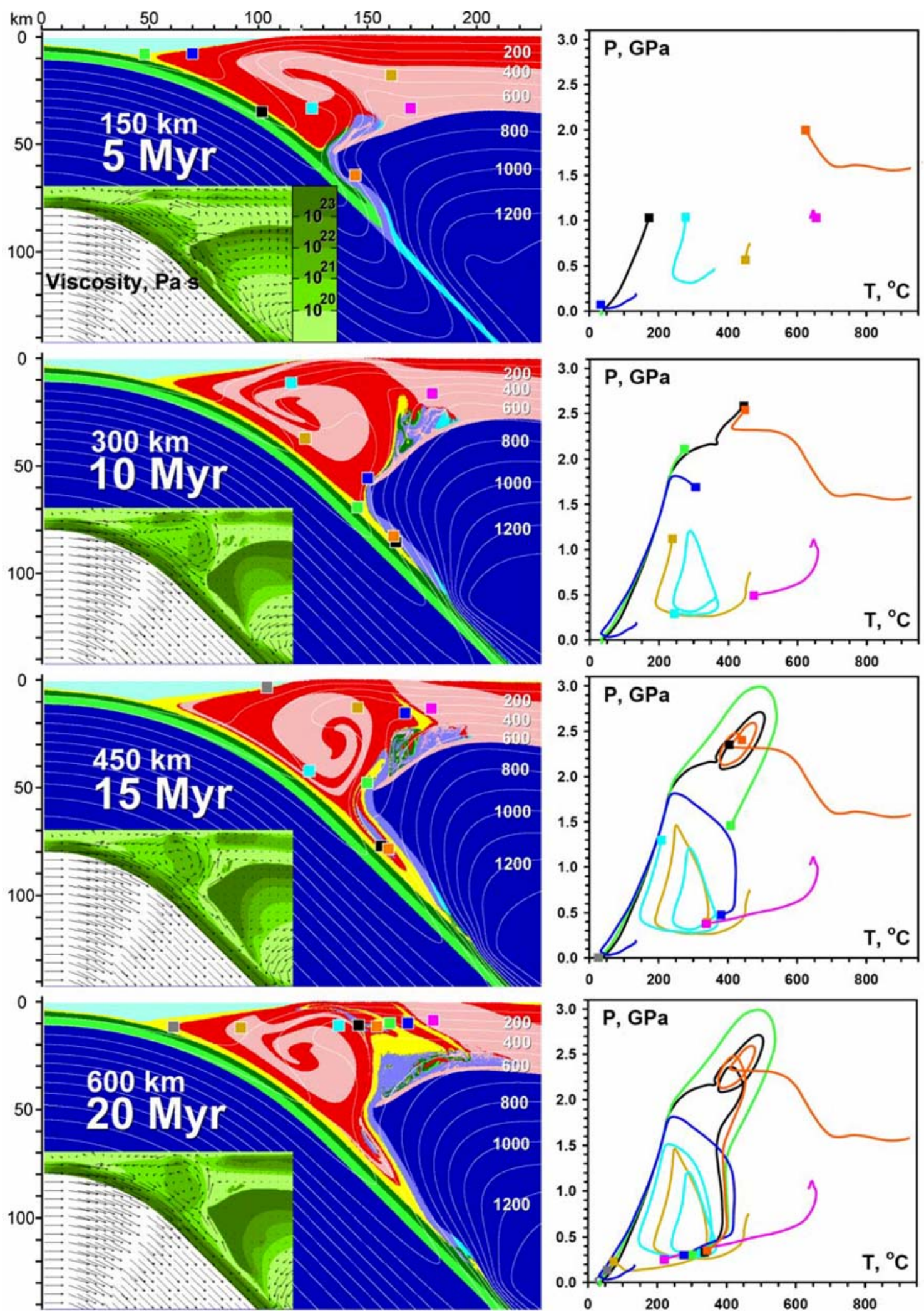

Fig. 4 Evolution of the model HYAA (model 1 in Table 2) of the active margin shown in four time slabs (5, 10, 15, and 20 Myr) corresponding to $150,300,450$, and $600 \mathrm{~km}$ of subduction. The color code is the same as for Fig. 2 

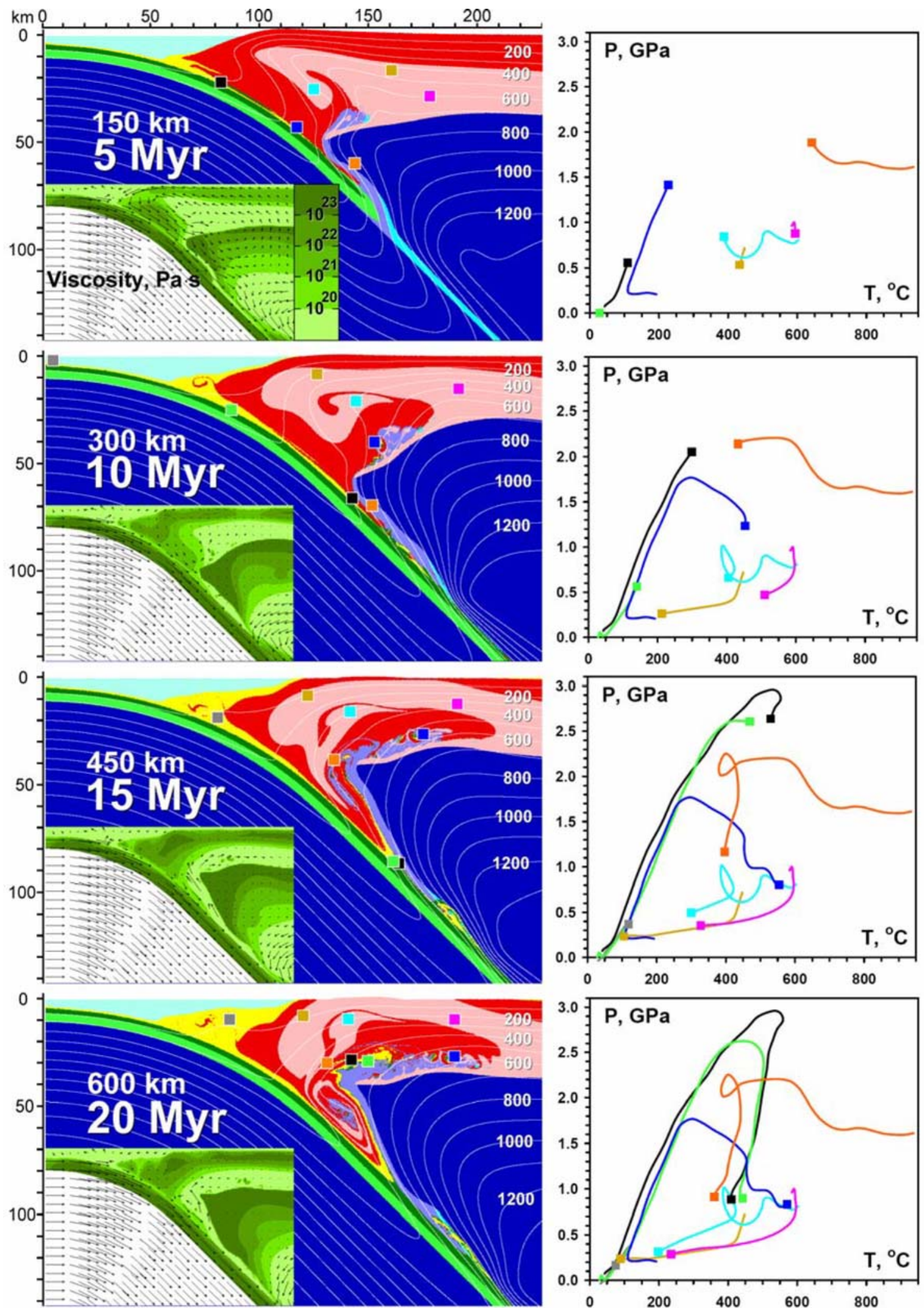

Fig. 5 Evolution of the model HYAC (model 3 in Table 2) of the active margin shown in four time slabs (5, 10, 15, and 20 Myr) corresponding to $150,300,450$, and $600 \mathrm{~km}$ of subduction. The color code is the same as for Fig. 2 

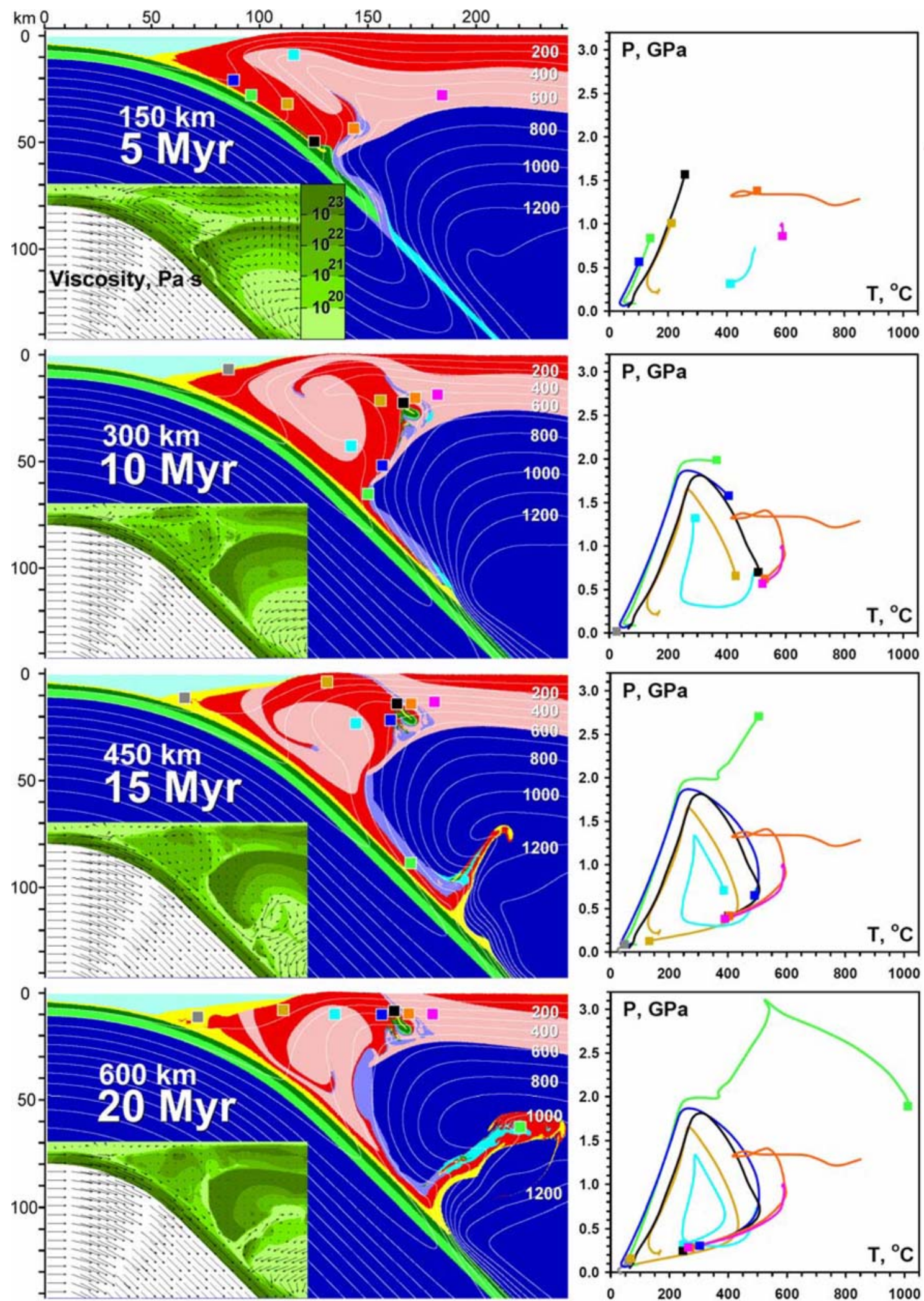

Fig. 6 Evolution of the model HYAF (model 7 in Table 2) of the active margin shown in four time slabs $(5,10,15$, and 20 Myr) corresponding to $150,300,450$, and $600 \mathrm{~km}$ of subduction. The color code is the same as for Fig. 2 

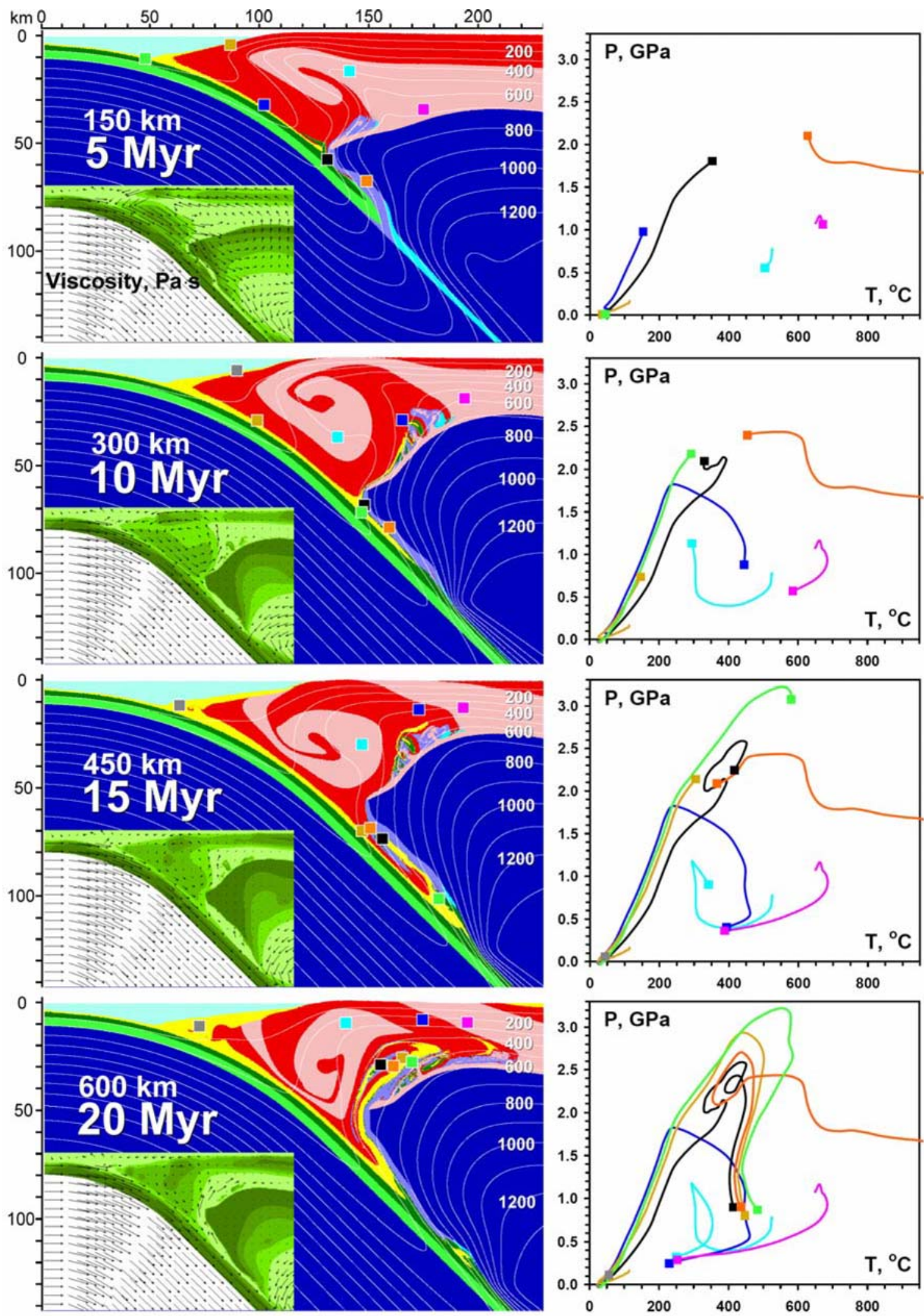

Fig. 7 Evolution of the model $H Y A G$ (model 8 in Table 2) of the active margin shown in four time slabs (5, 10, 15, and 20 Myr) corresponding to $150,300,450$, and $600 \mathrm{~km}$ of subduction. The color code is the same as for Fig. 2 

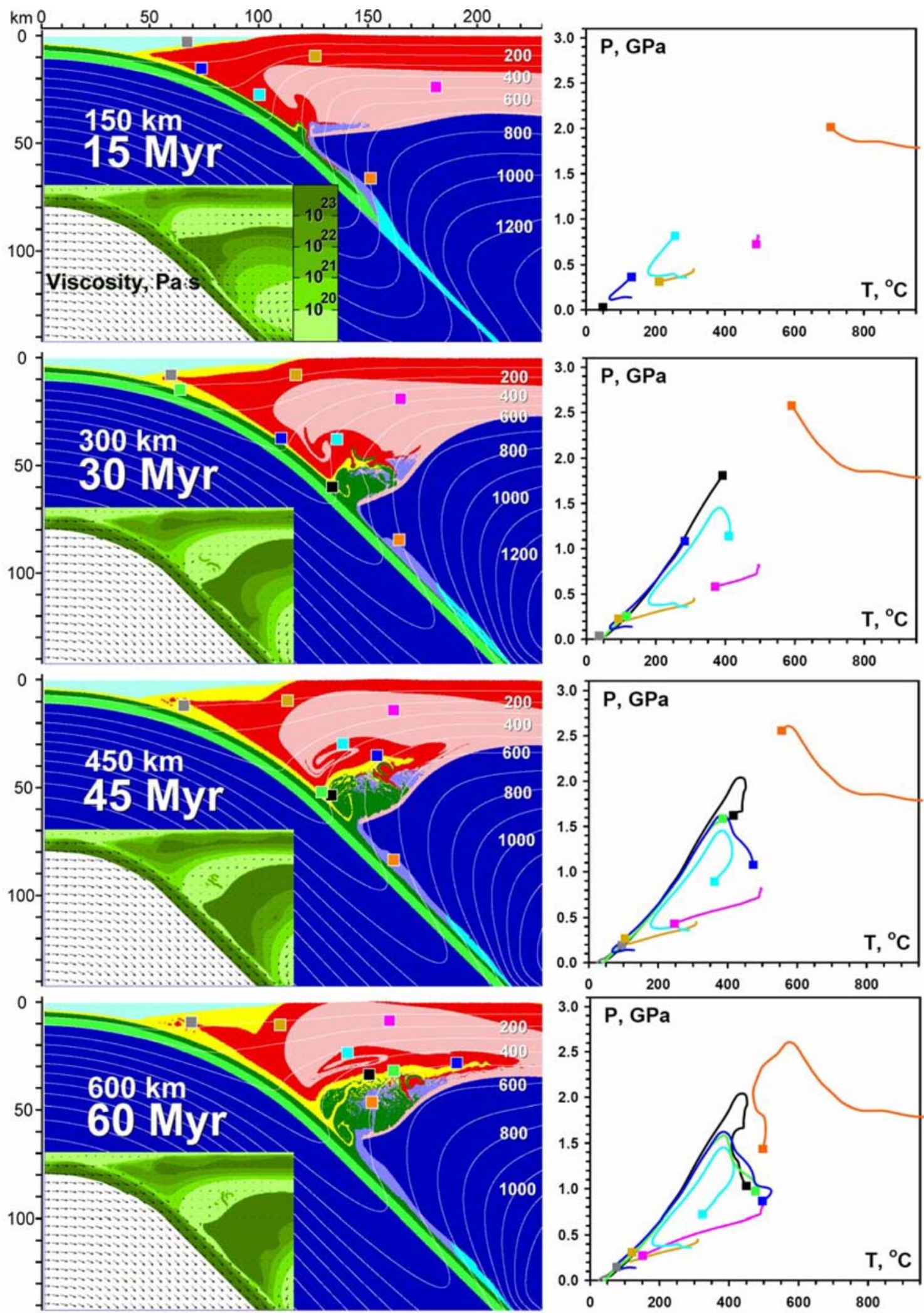

Fig. 8 Evolution of the model $H Y A H$ (model 9 in Table 2) of the active margin shown in four time slabs (15, 30, 45, and 60 Myr) corresponding to $150,300,450$, and $600 \mathrm{~km}$ of subduction. The color code is the same as for Fig. 2 

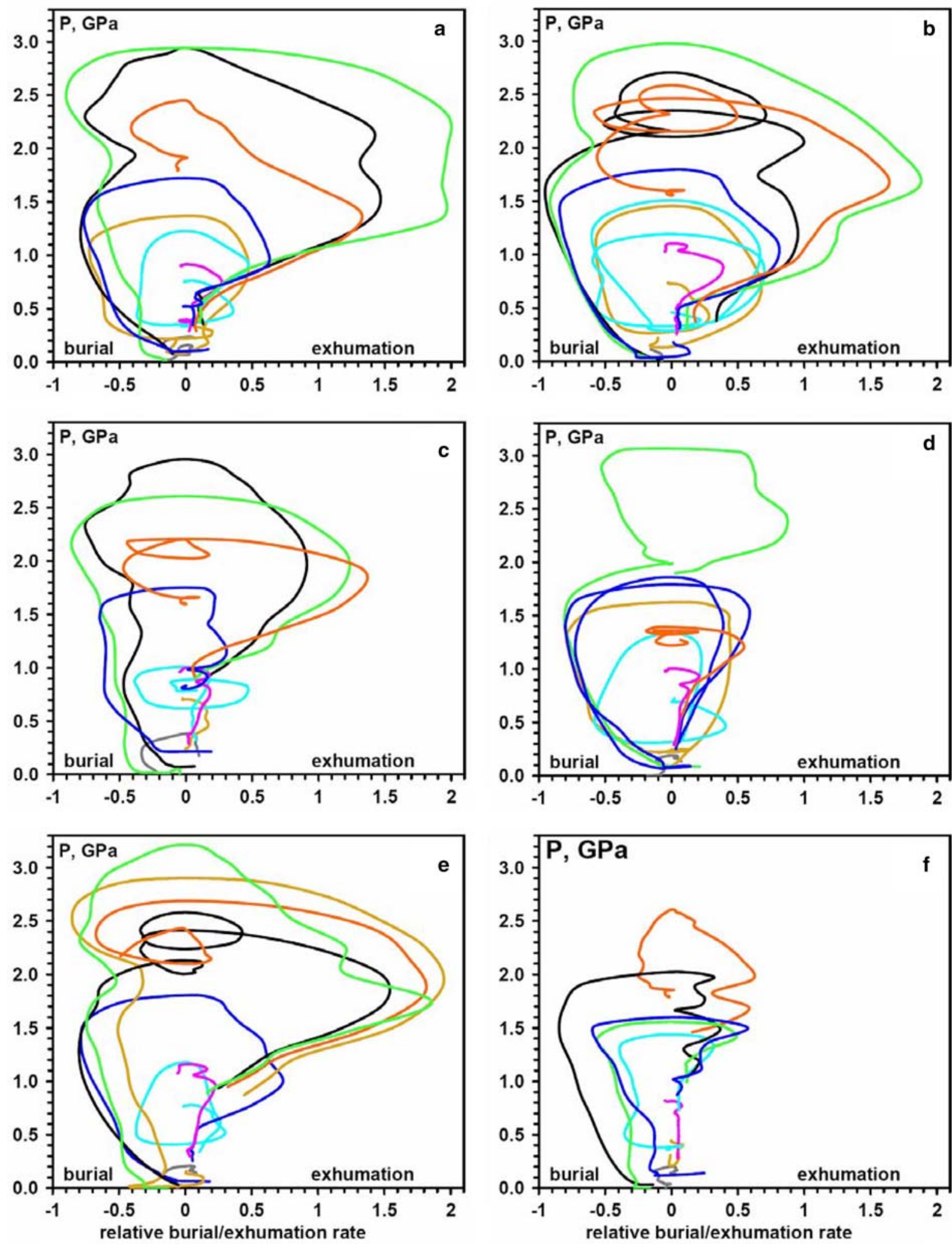

Fig. 9 Exhumation rates of selected markers for six numerical models shown in Figs. 2, 3, 4, 5, 6, 7, and 8: (a) $H Y A D$ (Model 4 in Table 2, Fig. 2), (b) $H Y A A$ (Model 1 in Table 2, Fig. 4), (c) $H Y A C$ (Model 3 in Table 2, Fig. 5), (d) $H Y A F$ (Model 7 in Table 2, Fig. 6), (e) $H Y A G$ (Model 8 in Table 2, Fig. 7), (f) HYAH (Model 9 in Table 2, Fig. 8). Exhumation rates are normalized to the maximal subduction burial rate calculated as $v_{\mathrm{sz}}=v_{\mathrm{s}} \sin (\alpha)$, where $v_{\mathrm{s}}$ is the relative plate velocity and $\alpha=45^{\circ}$ is the inclination of the subduction zone 
on the order of $10^{-13}-10^{-12} \mathrm{~s}^{-1}$ (Fig. 4, 15, 16, 17, 18, 19, $20 \mathrm{Myr}$, right column).

3 . The high velocity of extrusion of UHP rocks from the channel $(2-4 \mathrm{~cm} / \mathrm{a})$ is characteristic and commonly exceeds the burial velocity of these rocks $(1-1.5 \mathrm{~cm} / \mathrm{a})$ by a factor of 2-3 (Fig. 9a). This is a consequence of the focused return flow in the hanging wall portion of the subduction channel. The velocity field across the channel at $15-20 \mathrm{Myr}$ is characterized by a low viscosity (cf. viscosity field across the channel in Fig. 2, 15, $20 \mathrm{Myr}$ ) and Newtonian creep.

4. Moderate upward displacement of rocks within the crustal wedge results in exhumation of (U)HP rocks, attaining a position in the middle or upper crust. Also, a significant horizontal landward extrusion of these rocks at a mid- to lower crustal level is observed.

\section{Weak brittle crust model HYAA}

This numerical simulation (see Model 1 in Table 2, Figs. 4 and 9b) differs from our reference model HYAD by a lower brittle strength of the continental crust $\left(\lambda_{10}=0.9\right)$, which corresponds to that of the accreted sedimentary rocks. The development of the active margin structure in this model is very similar to that in the reference model HYAD (cf. Figs. 2, 4), with the following important features:

1. The accretionary complex is reduced in size (thin yellow layer in Fig. 4). The lack of a strength contrast precludes the formation of a rigid backstop. Instead, subduction erosion dominates at the front of the forearc, causing a steady subhorizontal transport of continental crust toward the trench, as evident from the velocity field shown in Fig. 4.

2. Pronounced upward displacement of rocks within the crustal wedge results in the transport of (U)HP rocks into an upper crustal level and to the surface; the horizontal extrusion of the exhumed (U)HP rocks into the landward lower crust is reduced.

3. While the subduction channel reaches only slightly deeper down and return flow of UHP rocks is strongly focused (cf. $P-T$ paths in Fig. 2, $20 \mathrm{Myr}$ ), as in the reference model HYAD, the exhumation velocity of UHP rocks from the subduction channel $(2-3 \mathrm{~cm} / \mathrm{a})$ tends to be slightly lower, commonly exceeding the burial velocity $(1.5-2 \mathrm{~cm} / \mathrm{a})$ by a factor of only 1.5-2 (Fig. 9b).

\section{Strong brittle crust model HYAC}

This numerical simulation (Model 3 in Table 2, Figs. 5, 9c) differs from our reference model HYAD by the increased brittle strength of the continental crust $\left(\lambda_{10}=0.6\right)$. This model shows the following features:
1. A deeper and wider accretionary complex develops, compared to the reference model, as a consequence of a rigid backstop system developing due to the significant contrast in the brittle strength between the accreted sedimentary rocks $\left(\lambda_{10}=0.9\right)$ and the continental crust $\left(\lambda_{10}=0.6\right)$ forming the backstop. As a consequence, the circulation patterns within the crustal wedge and within the accretionary complex are clearly separated (cf. velocity field in Fig. 5, $20 \mathrm{Myr}$ ).

2. The upward movement of rocks within the crustal wedge is less important, compared to the reference model. Instead, horizontal landward extrusion of (U)HP rocks and underplating dominates.

3. The circulation pattern in the subduction channel is clearly separated from that in the crustal wedge (Fig. 5, $20 \mathrm{Myr}$ ). Less material is extruded from the channel. This seems to be related to the higher strength and slower deformation of the upper crust, which needs to accommodate the landward accretion of (U)HP rocks in the lower crust.

4. The exhumation rate of UHP rocks from the subduction channel is lower, compared to both previous models HYAD and HYAA. The return flow in the channel is still focused, however, and the exhumation rate of the UHP rocks $(1.5-2.5 \mathrm{~cm} / \mathrm{a})$ systematically exceeds the burial rate $(1-1.5 \mathrm{~cm} / \mathrm{a})$ by a factor of 1.5-2 (Fig. 9c).

\section{Dislocation creep of crust model HYAF}

This numerical simulation (Model 7 in Table 2, Figs. 6, 9d) differs from our reference model by the low stress $\left(\sigma_{\mathrm{tr}}=0.03 \mathrm{MPa}\right)$ for the transition from diffusion to dislocation creep for all crustal rocks. With this unrealistic low value, ductile flow of crustal material in the crustal wedge and subduction channel is forced to take place by thermally activated power law creep. As a consequence, this model differs notably from all previous models:

1. The wedge-shaped subduction channel is characterized by a weak and diffuse return flow. This is consistent with our previous analytical results (Gerya and Stöckhert 2002), where a slower and less focused return flow in the subduction channels was predicted for material deforming by power law creep compared to Newtonian behavior.

2. A significant portion of buoyant crustal rocks and serpentinized mantle is subducted to greater depths, beyond the channel, and develops finger-like oblique diapiric structures penetrating the mantle wedge (Fig. 6, 15, $20 \mathrm{Myr}$ ). In contrast to commonly considered thermal and chemical plumes, the temperature distribution within this structure is inverted, the core being colder than the rim. Similar structures ("cold plumes") were studied numerically by Gerya and Yuen (2003a) for the oceanic subduction process. It was also proposed that such structures may provide an important contribution to the source of 
magma beneath volcanic arcs (Gerya et al. 2004). The apex of the "cold plume" in our model is located at 160-190 km distance from the trench and a depth of $50-70 \mathrm{~km}$. There, the temperatures of about $1,000^{\circ} \mathrm{C}$ (Fig. 6, $20 \mathrm{Myr}$ ) exceed the wet solidus of subducted crustal rock materials (e.g., Schmidt and Poli 1998; Poli and Schmidt 2002). Significant melting of crustal rocks is therefore expected to develop within this structure, providing a possible source of magma with crustal signature beneath the region where the volcanic arc typically develops at the surface.

3. UHP metamorphic rocks are not exhumed from the channel at the $20 \mathrm{Myr}$ time slab (Fig. 6, $20 \mathrm{Myr}$; see also Fig. 9d).

4. Upward movement of HP metamorphic rocks within the crustal wedge is not associated with the horizontal extrusion of HP metamorphic rocks into the landward lower crust or underplating, as observed in models HYAD, HYAA, and HYAC.
Low hydration rate model HYAG

This numerical simulation (Model 8 in Table 2, Figs. 7 and 9e) differs from our reference model HYAD by the low rate of mantle wedge hydration $(A=0.025)$. Development of this model is very similar to the reference one with the following features:

1) The development of the subduction channel is delayed by $\sim 5 \mathrm{Myr}$ due to the slower hydration and more sluggish weakening of the overriding mantle lithosphere. At a given time slab, the subduction channel is narrower compared to the reference model.

2) After $20 \mathrm{Myr}$ of subduction, the UHP rocks returning from the subduction channel only reach a lower crustal level that is similar to the situation characteristic of the reference model at an earlier stage (compare Fig. 2 at $15 \mathrm{Myr}$ with Fig. 7 at $20 \mathrm{Myr})$.
Fig. 10 Scheme visualizing the characteristic trajectories of geologic units (zones A to D) in the subduction zone and their position in the pre-collisional orogenic belt, with characteristic materials, metamorphism, and structural record indicated. The $20 \mathrm{Myr}$ time slab corresponding to $600 \mathrm{~km}$ of subduction for the reference model $H Y A D$ is shown for comparison. The color code is the same as for Fig. 2 french sediments and oceanic material from lower plate

very low grade

accretionary prism

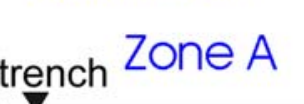

continental crust of upper plate

HP + Barrovian overprint

basement and cover nappes

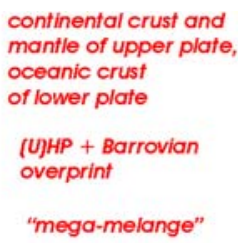

continental crust and mantle of upper plate,

oceanic crust

of lower plate

(U)HP + Barrovian overprint

"mega-melange"

continental crust of upper plate

no contemporaneous metamorphism

little deformation

\section{Zone B}
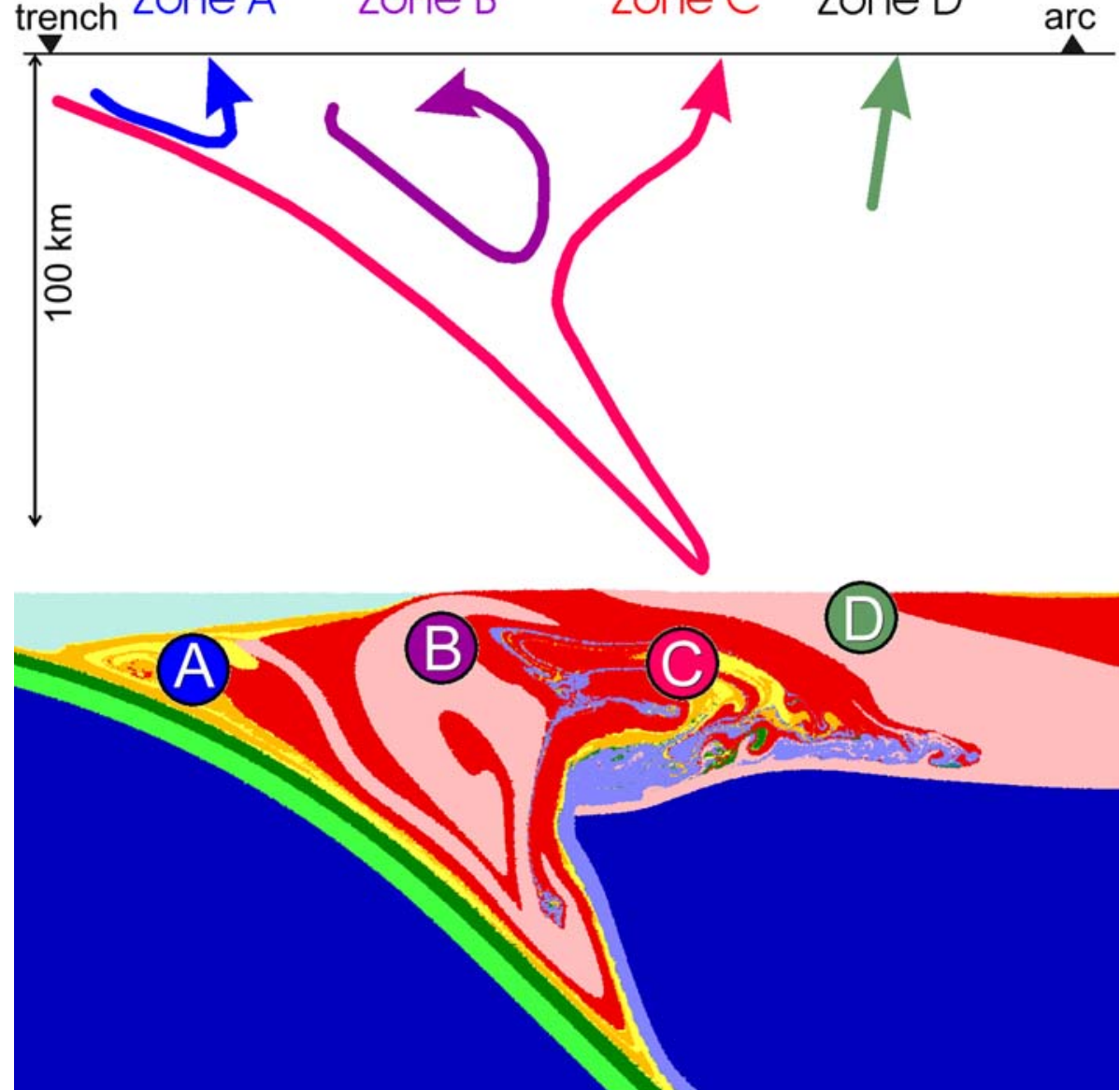


\section{Slow subduction model HYAH}

The last numerical simulation HYAH (Model 9 in Table 2, Figs. 7 and 9f) differs from our reference model by the low subduction rate of $1 \mathrm{~cm} / \mathrm{a}$, compared to $3 \mathrm{~cm} / \mathrm{a}$ in the reference model. The structural evolution in this model strongly differs from that in the reference model, as it turns out to be strongly affected by gravitational redistribution processes:

1. The subduction channel is very narrow and composed of serpentinized mantle only. Return flow from this channel is not significant. Absence of crustal rocks inside the channel is apparently due to slower subduction, with subduction drag forces being outweighed by positive buoyancy forces.

2. The HP rocks are accreted to the lower crust in the form of a flattened wedge-like structure propagating landward. No exhumation of these rocks toward higher crustal levels occurs during ongoing subduction.

3. The relative vertical position of the different rock types inside the crustal wedge is affected by their density, with more dense material tending to accumulate at deeper levels.

\section{General features of the simulations}

Here, we summarize the general features observed in our reference model HYAD, which may be more or less pronounced in the other models. As such, our models appear to be robust with respect to the chosen properties and parameters, as far as these features and the resulting structures are concerned.

Within a few million years from the onset of subduction, subduction erosion begins to remove continental crust from the front of the upper plate. Most of this material is emplaced beneath the frontal part of the forearc, where former upper and lower continental crust becomes wound up in a marble cake-like fashion forming a wide wedge reaching a depth of about $50-70 \mathrm{~km}$. Minor amounts of continental crust are carried further down, to depths of $100 \mathrm{~km}$ and more, into the narrowing subduction channel and partly return by forced flow, mixing up with material derived from the subducted oceanic crust and the hydrated mantle at the hanging wall. These returning HP or UHP metamorphic slices become extruded from the subduction channel at the landward side of the marble cake wedge. Controlled by the strength of the overlying continental lid, both the wedge and the landward HP and UHP metamorphic megascale melange progressively tend to warp upward and may eventually become exposed by erosion. After about $600 \mathrm{~km}$ of subduction ( 20 Myr of subduction with a rate of $3 \mathrm{~cm} /$ year) an active continental margin structure with four distinct zones (Fig. 10) has developed, which are (landward from the trench):
(A) An accretionary complex of at best low-grade metamorphic sedimentary material.

(B) A wedge of deformed continental crust derived from the front of the overriding active margin by subduction erosion, with medium-grade HP metamorphic overprint and a convoluted internal structure comparable to a marble cake, appearing as metamorphic nappes with alternating upper and lower crustal provenance.

(C) A megascale melange composed of HP and UHP metamorphic oceanic and continental crust, and hydrated mantle, all intermingled within and subsequently extruded from the subduction channel.

(D) An upward tilted frontal part of the remaining lid, with exposed deeper levels of the overriding continental crust juxtaposed against zone $\mathrm{C}$.

The principal features of the four zones A-D are summarized in Fig. 10. The degree of exposure of the last three zones is critically dependent on the brittle strength of the upper continental crust and the subduction rate. In the following discussion of our reference model (Figs. 2, 3 ) and the other five selected models (Figs. 4, 5, 6, 7, 8) we refer to these four zones, their shape, extent, and configuration, and explore the variations in the numerical results with changing input parameters.

\section{Discussion}

Particle trajectories and structures in the simulations

In this section we compare the particle trajectories and resulting structures with the chosen parameters and examine the influence of assigned material properties on the structure of the simulated orogenic belt and the record of the metamorphic rocks, starting with zone A (Fig. 10). The $P-T-t$ paths displayed for selected markers are representative of the respective tectonic units.

In model HYAA (weak upper continental crust, Fig. 4) the shallow frontal wedge (zone A) is poorly developed and little material is accreted, while the accretionary complex is wide in model HYAC (strong upper continental crust Fig. 5). This indicates that the strength of the upper crust, in our simulations imposed by variation of the pore fluid pressure coefficient, has a marked influence on the development of the accretionary wedge. In the models, a wide and deep accretionary complex requires a rigid backstop. In model HYAA (Fig. 4), the sediment is continuously supplied by erosion of the uprising broad wedge (zone B), while the shallow frontal accretionary wedge (zone A) is not exposed above sea level and hence does not undergo erosional denudation in its rear part. A large portion of the sedimentary material is carried down beneath a mechanically weak seaward dipping backstop, together with continental crust of the overriding plate affected by subduction erosion. 
In all models, continental material removed from the landward slope of the trench or the base of the crust in the frontal forearc is continuously carried down to beneath the forearc. This type of subduction erosion is documented at several active continental margins showing little accretion (for review, see von Huene and Scholl 1991). In our simulation, the process is strongly enhanced for a weak upper crust (model HYAA, Fig. 4), and less effective for a strong upper crust (model HYAC, Fig. 5). Subduction erosion affects both upper and lower continental crust of the forearc, and material derived from both levels (discriminated by color in Figs. 2, 4, 5, 6, 7, 8, but with identical mechanical properties) becomes stretched out and wound up as schlieren forming a broad wedge (zone B). The schlieren on the crustal scale may be compared to metamorphic nappes, both with respect to thickness (on the order of several kilometers) and aspect ratio (on the order of 10). The characteristic length scale of intermingling between units of different provenience has been found to depend on the viscosity of the materials, with higher viscosities leading to more extensive coherent nappe structures, and lower viscosities to a melange-type pattern (Gerya et al. 2002). The amount of oceanic crust and hydrated mantle material incorporated into the convolute structure of zone B (Fig. 10) is subordinate in all models and not significantly affected by the choice of parameters. This may explain the widespread occurrence of small portions of metabasic rocks and peridotites or serpentinites in highly deformed and medium- to high-grade metamorphic continental crust.

Rocks from a very wide spectrum of sources are carried down, intermingled in, and extruded from the subduction channel, typically reaching to a depth of about $100 \mathrm{~km}$. Return flow in the hanging wall of the subduction channel brings material back to a crustal level. This material becomes extruded in a megascale melange (zone $\mathrm{C}$ ) on the landward side of the broad "marblecake" wedge (zone B). It comprises oceanic or trench sediments, slices of subducted oceanic crust, slices of upper or lower continental crust from the front of the active margin, and hydrated mantle rocks from the overriding plate, with HP and UHP metamorphic overprint, depending on the depth reached in the subduction channel. The characteristic length scale of the individual units is on the order of kilometers or less, i.e., about one order of magnitude smaller than the schlieren in the marble cake wedge (zone B), when compared with the metamorphic nappes. This length scale leads to the description as megascale melange, the units of which reveal contrasting source rocks, contrasting maximum depths of burial, and contrasting $P-T-t$ paths.

The shape of zone $\mathrm{C}$ developing with progressive evolution of the model is strongly affected by the choice of parameters. For a weak upper crust (model HYAA), in the final time slab (20 Myr) zone $\mathrm{C}$ has a low aspect ratio and steep boundaries with zones $\mathrm{B}$ and $\mathrm{D}$ intruding between these zones from below. For a strong upper crust (model HYAC), zone $\mathrm{C}$ has a high aspect ratio and horizontally underplates zones B and D.
Mantle hydration with conversion into serpentinite, for which a low viscosity and Newtonian behavior is assumed (Gerya et al. 2002), is essential for the development of the subduction channel. A low hydration rate (model HYAG, Fig. 7) delays the development of the subduction channel and the onset of effective return flow. While in our models a subduction channel readily develops for a subduction rate of $3 \mathrm{~cm} /$ year, it does not for a rate of subduction of only $1 \mathrm{~cm} /$ year (model HYAH, Fig. 8). This suggests that buoyancy forces can outweigh drag forces at low rates of subduction, and that exhumed HP and UHP metamorphic assemblages forming a megascale melange (zone C) may thus be restricted to convergent margins with a moderate to high subduction rate.

A subduction channel with return flow and exhumation of UHP metamorphic rocks does not develop in model HYAF (Fig. 6), where a power law rheology is assigned to the entire crustal material. This type of mechanical behavior leads to deeper subduction of crustal material and eventual oblique protrusion into the mantle wedge, with the head of this cold plume (Gerya and Yuen 2003a) reaching a depth of about $60 \mathrm{~km}$ at a position 150-200 km landward from the trench, i.e., beneath a site where the magmatic arc is typically found at the surface. We speculate that such behavior could affect the source region of arc magmatism with continental signature. It must be borne in mind that this pattern is affected by buoyancy of crustal material and that the change in density during (U)HP metamorphism of the subducted material, not accounted for in the simulation, may have a marked influence.

At a distance of about $100 \mathrm{~km}$ from the trench, the continental crust of the overriding plate is little affected by the subduction process and forms a rigid lid (zone D). The lid becomes warped up on the trenchward side, due to underplating of the megascale (U)HP melange (zone C); the upwarping could be further accommodated by a backthrust during a later collision stage in a real orogenic belt, like in the European Alps (e.g., Schmid et al. 1996, 2004), which was shown in numerical models (e.g., Beaumont et al. 1996; Pfiffner et al. 2000; Ellis et al. 2001).

While the internal structure of the tilted continental crust in zone $\mathrm{D}$ is not significantly changed during the evolution of the active margin, the trenchward continental crust in zone B is intensely reworked with a stage of HP metamorphic overprint in most units. Depending on the strength of the upper crust, zone B can remain covered by a lid corresponding to zone $\mathrm{D}$ for the entire period examined in the simulation (model HYAC, Fig. 5).

After circulation of crust in the broad convolute wedge (zone B) and extrusion from the deep-reaching subduction channel (zone C) the structural grain is predominantly horizontal or shallow-dipping. Steep zones develop on the flanks of the marble cake wedge, with a convolute structure on a length scale of tens of kilometers, while the material extruded from the subduction channel spreads horizontally on the landward side of the convolute marble cake wedge and protrudes 
beneath the rear part of the lid. Such structures may be compared to the structures exposed in mountain belts after collision.

\section{Time scales}

The time scales inherent in the simulated evolution are governed by the imposed plate velocity. For the chosen moderate convergence rate of $3 \mathrm{~cm} /$ year, the characteristic structure of the active continental margin develops within about $20 \mathrm{Myr}$ and (U)HP metamorphic rocks may become exposed at the surface a few million years later, facilitated by a weak upper crust (models HYAD and HYAA, Figs. 2 and 4). Thus, even for the moderate convergence rates imposed in our models, the time spans inherent in the simulated metamorphic and tectonic evolution are short. When compared with the history of natural orogenic belts, such time spans may be too short to be properly resolved by isotopic dating for preMesozoic tectonic processes, due to limited resolution of the dating techniques.

Our experiments also show an important new feature: focusing of the exhumation flow in the subduction channel dramatically increases the exhumation rates of UHP metamorphic rocks (Fig. 9). In our previous analytical study (Gerya and Stöckhert 2002) and numerical modeling of oceanic subduction process (Gerya et al. 2002) we calculated exhumation rates of about $1 / 6$ to $1 / 3$ of the subduction burial rates, assuming a subduction channel closing at depth and a uniform, temperature independent of either power law or Newtonian rheology across the channel. However our new results suggest that transition from dislocation to diffusion creep across the channel may result in the exhumation rates even exceeding the rate of subduction and burial by a factor of 1.5-3. Very rapid exhumation of UHP metamorphic rocks can thus be achieved at active continental margins, exceeding by far the averaged values derived from geochronological bounds (e.g., Gebauer et al. 1997; Amato et al. 1999; Rubatto and Hermann 2001). As indicated by our simulations, the focused rapid return flow requires a Newtonian behavior of the material in the subduction channel and is not realized for a power law rheology (model HYAF, Fig. 6) or slow subduction (model HYAH, Fig. 8).

Shape of the $\mathrm{P}-\mathrm{T}$ paths and temperatures of metamorphism

The shape of the predicted $P-T$ paths corresponds to those typically inferred from thermobarometric analysis of exhumed HP and UHP metamorphic rocks (e.g., Spalla et al. 1996; Duchêne et al. 1997, Carswell and Zhang 1999; Ernst 1999, 2001; Kurz and Froitzheim 2002). The position of the markers, for which the $P-T$ paths are shown in Figs. 2, 4 and 6, is chosen in a way to represent a series of rocks closely spaced in a horizontal level, envisaged to represent a future erosional land surface after collision. This choice visualizes the contrast in the $P-T$ paths, as well as in the provenience of the protolith and the timing of peak metamorphism, which can be detected in immediately adjacent tectonic units or "nappes" in an orogenic belt. Notably, some of the particle trajectories imply loops in the $P-T$ paths, for which an unequivocal record in natural rocks remains to be identified.

When comparing the $P-T$ paths obtained in the simulations (Figs. 2, 4) with those established for HP and UHP metamorphic rocks in the orogenic belts (e.g., Schertl et al. 1991; Zimmermann et al. 1994; Spalla et al. 1996; Duchêne et al. 1997; Reinecke 1998; Carswell and Zhang 1999; Ernst 1999, 2001; Ernst and Liou 1999; Kurz and Froitzheim 2002), a minor discrepancy in the peak temperatures is evident. In the simulations, the maximum temperatures reached during HP metamorphism are mostly between 400 and $500^{\circ} \mathrm{C}$, while eclogite facies metamorphism in the above examples typically indicates temperatures of $500-600^{\circ} \mathrm{C}$, and up to $800^{\circ} \mathrm{C}$ or more for UHP metamorphic rocks. The thermal structure of the subduction zone depends on the rate of subduction (e.g., Peacock 1996), which is taken as $3 \mathrm{~cm} /$ year in most of the simulations presented here. A lower rate would imply higher temperatures of metamorphism, but also preclude effective return flow (model HYAH, Fig. 8). Apart from the arbitrarily chosen initial conditions, we suspect that this discrepancy may be related to the choice of the antigorite stability field to delineate the low-viscosity subduction channel. This assumption limits the back flow of low-viscosity material to a cool realm. If we accept a low viscosity of the subduction channel material due to the presence of a fluid phase at UHP metamorphic conditions (e.g., Scambelluri and Philippot 2001; Stöckhert et al. 2001), allowing dissolution precipitation creep and fluid-assisted granular flow (Stöckhert 2002), and temperatures beyond those defined by the antigorite stability field, (U)HP metamorphic rocks that have experienced higher peak metamorphic temperatures can be extruded from the subduction channel. A significant increase in radioactive heat production or in shear heating within the subduction channel may also lead to higher peak metamorphic temperatures (e.g., Burg and Gerya 2005).

Comparison with real convergent continental margins

There are two ways to compare the results of the simulations with the structure of real convergent continental margins:

1. Continental margins at presently active subduction zones. Here, predictions on the deep structure are exclusively based on geophysical experiments, with additional indirect information based on the geologic record at the surface.

2. Mountain belts in zones of continent-continent collision, where the record of fossil pre-collisional pro- 
cesses in the deep levels of the upper plate is accessible owing to post-collisional exhumation, albeit necessarily modified during collision. When comparing the simulations with the structure of real margins one must be aware of the fundamental limitations inherent in the models. The most important limitation is probably the grossly simplified crustal structure and the neglected inhomogeneities, particularly in the continental crust. The structure of a real margin may be largely controlled by prescribed heterogeneities in material and crustal thickness, as well as by preexisting zones of weakness, like evaporite layers or fault zones developed previously during rifting of the continental margin. Such discontinuities are not included in our simulations. Also, new discontinuities - as large-scale faults - cannot develop in the present simulations.

When comparing the simulations with the structural record exposed in collisional orogens and with the $P$ $T-t$ paths derived for exhumed rocks, it must be borne in mind that our simulations address the development of an active margin prior to collision. Collisional belts, such as the European Alps, provide insight into the internal structure, but in a state strongly affected by deformation during collision. This leaves uncertainty with respect to a pre-collisional structure. For instance, the boundary between zones B or C and D (Fig. 10), as defined above, is likely to be modified later during the collision stage in the form of a so-called backthrust, as observed in the Alps (e.g., Schmid et al. 1996) and developed in numerical simulations (e.g., Beaumont et al. 1996; Pfiffner et al. 2000; Ellis et al. 2001). Furthermore, a 2-D model implies plane strain, which probably is the exception rather than the rule at active continental margins, with partitioning into plate boundary normal shortening and strike slip motion being a common situation (e.g., Cashman et al. 1992; Cembrano et al. 2000).

Nevertheless, we are confident that the general features of the models can be compared with predictions on the deep structure of active convergent margins, and with the respective structural and metamorphic record accessible after exhumation in collisional orogenic belts. However, these comparisons must by no means be misunderstood as attempts to simulate a specific existing structure. The merits or shortcomings of the simulation need to be tested against the natural structure and record by the specialists in these regions.

For instance, taking the central Andes as a classical example for an active continental margin, the perspective of a comparison with our simulations is restricted to three primary reasons:

1. With subduction going on at least since the early Mesozoic, the time span of ongoing convergence is one order of magnitude longer than the time span examined in our simulations.
2. The present day convergence rate is high compared to that in our models, where the Naszca plate is subducted beneath the Andes.

3. The dip of the plate interface is shallower compared to that in our simulations.

Information on the structures and material properties at depth for the subduction zone beneath the central Andes was obtained by a wide spectrum of geophysical experiments (Oncken et al. 2003). As no Mesozoic or Tertiary metamorphic rocks are exposed so far by denudation, and crustal shortening is comparatively unimportant (except in the backarc, not covered by the present simulations), the proposed structural models may be compared to our simulations with a strong upper crust (model HYAC, Fig. 5). This model is characterized by a rigid lid undergoing little uplift and erosion, similar to what is inferred for the pre-Miocene Andes. For the region corresponding to the exit of the subduction channel and the lower lobe (zone B2) in our model HYAC (Fig. 5), geophysical surveys of the central Andean forearc reveal a heterogeneous structure, peculiar rock properties, and intense seismicity (Yuan et al. 2000; Oncken et al. 2003). It remains to be tested whether the properties of the deep crust and the mantle wedge can be explained by material extruded from a subduction channel, with parts of the lower crust corresponding to zone $\mathrm{C}$ of our simulations. If so, subduction erosion and crustal underplating after cycling through the subduction channel could be a possible mechanism for crustal thickening in the Andes. For instance, extrusion of material from a subduction channel was recently proposed by Meier et al. (2004) as a possible cause for surface uplift in the forearc of the Hellenic subduction zone.

In contrast to the Andes, the European Alps represent a collisional belt and-owing to post-collisional uplift and denudation - provide insight into deeper levels of the former active margin. A comparison with our simulations is subject to the identification of the effects of collision. Despite all uncertainties, the spatial arrangement, the relative width, the provenience of the materials, the inferred structural and petrologic record, and the simulated $P-T$ paths for rocks in zones A to D (see Figs. 2, 10) come quite close to the respective pattern in the Alps (Stöckhert and Gerya 2005).

In the Alps, the Penninic realm (e.g., Schmid et al. 2004) is comprised of nappes of continental and oceanic material, similar to zones B and C in our simulations. The paleogeographic arrangement of these units has been reconstructed from their present structural setting, and a complex pattern of oceanic troughs and microcontinents has been inferred (e.g., Debelmas et al. 1983) which is a matter of continuous debate (e.g., Pfiffner et al. 1990; Polino et al. 1990; Schmid et al. 1996; Froitzheim 2001; see Schmid et al. 2004 for a comprehensive review). Polino et al. (1990) have proposed that subduction erosion could be an alternative to the imbricate stack of paleogeographic realms entering the subduction 
zone one after the other. The authors pointed out that the minimum horizontal dimensions of a typical modern microcontinent embedded in oceanic realms, with the respective passive margins, are likely in the range of hundreds of kilometers. More importantly, the thickness of the continental crust in such slivers embedded in oceanic crust can be expected to be at least about $20 \mathrm{~km}$. The paleogeographic reconstructions therefore predict a volume of continental crust exceeding that of the typical Alpine basement nappes and orogenic root by one to two orders of magnitude (Polino et al. 1990). For reasonable dimensions of continental slivers between oceanic domains, the actual volume of continental crust preserved in the Alps requires subduction of a considerable amount of continental crust (e.g., Schmid et al. 1996; Ellis et al. 1999). A marked discrepancy would still remain when only the upper crust of the incoming continental terranes would be accreted, as in the numerical simulations by Ellis et al. (1999), with the lower half of the continental crust being subducted. Consequently, models proposed for the tectonic evolution of the Alps require subduction of a considerable amount of continental crust (e.g., Schmid et al. 1996).

An alternative scenario would be derivation of the continental slices in the Alpine nappe pile by subduction erosion (von Huene and Scholl 1991) from the front of the upper plate. In this case, the width of the continental slices would be arbitrary and would not necessarily correspond to the width of a typical microcontinent with passive margins on both sides. Also, there would be no restrictions in terms of crustal thickness, and the slices could be derived from any level of the crust at the front of the forearc. Subsequent circulation of the slices through either a wide more frontal wedge (to finally end up in zone B in our simulation) or a deep narrow subduction channel (to end up in zone C), leaves many degrees of freedom for their intermingling with oceanic and sedimentary material deposited on both oceanic or thinned continental crust, as visualized by our simulation (see different markers in Fig. 2). Our simulation supports the idea that interleaving continental and oceanic or metasedimentary nappes can form at a simple active continental margin undergoing subduction erosion. If true, there would be no general need for a more complex paleography with microcontinents and several oceanic branches, with the resulting difficulty to resolve volumetric problems (Polino et al. 1990), and subduction of large amounts of continental crust would not be required. Clearly, this statement is not to question a priori the validity of the paleogeographic reconstruction of the Alps (e.g., Schmid et al. 1996, 2004; Stampfli et al. 1998), but thought to provoke a critical analysis of the potential structure of the Apulian passive margin prior to subduction (with possible extensional allochthons; Froitzheim et al. 1996; Schmid et al. 2004) and on the processes involved in its transformation into an active margin.

We propose that the structures developed in our simulations (zones B and C) are not completely dissimilar to those that could have existed in the pre-collisional
Alpine belt, clearly notwithstanding the crustal heterogeneity and paleogeographic complexities. In addition to the gross structural pattern, the similarity also comprises the length scales, the time scales, and the $P-T$ paths of individual rocks from various settings (Stöckhert and Gerya 2005). In our simulations, the structural evolution of the orogenic belt is dominated by large-scale curl, while in kinematic reconstructions of the central Alps the HP metamorphic nappes are commonly interpreted to represent imbricate slices with contrasting depth of maximum burial and exhumation by forced extrusion (e.g., Schmid et al. 1996).

Similarly, numerical simulations of episodic accretion of small continental terranes embedded in oceanic crust (Ellis et al. 1999) result in accretion of the upper crust, becoming squeezed out as huge crustal scale fold nappes, while the strong lower crust of the continental terranes, with mechanical properties corresponding to those of the adjacent oceanic crust, becomes subducted. The material squeezed out in the huge fold nappes is not buried to great depths, however, and HP to UHP metamorphic conditions are not attained in those simulations.

The structure of zone D (Fig. 10) in our simulations can be compared to that of the Southern Alps, south of the Insubric fault. There, the northernmost section is warped up and the basement is exposed, while the Permian to Mesozoic sedimentary cover is preserved further to the south. Basically the same structure is already developed in our simulation prior to collision, enhanced by a weak upper crust, due to the upwarping of the wide wedge and the material extruded from the subduction channel, which causes progressive uplift and erosion of the lid. Our simulation (Figs. 3, 10) suggests that a large part of the exhumation of units comparable to the Sesia zone and the Penninic HP metamorphic nappes could take place prior to collision, with upwarping of the frontal part of the overriding lid (zone D, Fig. 10), and that collision-related backthrusting makes up only a portion of the differential uplift.

Finally, a comparison between the pre-collisional structure of the active convergent margin, as achieved in our simulation, and the actual crustal structure of the Alps as revealed by geologic and reflection seismic studies (e.g., Pfiffner et al. 1990, 1997; Schmid et al. 1996) suggests that during collision material from beneath the forearc was displaced backward by the underthrusting European continent. As a consequence, the frontal part of the shallow forearc represented, e.g., by the Prealpes Romandes and the Penninic flysch units (e.g., Schmid et al. 2004), which can be taken to correspond to zone A in our simulations, was thrust upon the Helvetic fold and thrust belt developing in the sedimentary cover of the underthrusting European passive margin.

The effects of collision are not addressed in the present set of simulations. Subduction of buoyant crust is expected to strongly affect the plate boundary force balance. This may trigger slab break-off (Davies and von Blanckenburg 1995; von Blanckenburg and Davies 1995), syn-collisional buoyant exhumation of the sub- 
ducted crust (e.g., Chemenda et al. 1995), and magmatic activity (von Blanckenburg and Davies 1995). Also, the processes leading to exhumation of (U)HP metamorphic rocks may change during the transition from oceanic subduction to collision; forced extrusion of subducted continental crust may become important during continental collision (Chemenda et al. 1995; Ellis et al. 1999; Burov et al. 2001).

\section{Conclusions}

The results of our 2-D simulations, despite all limitations in the complexity of preexisting structure and simplification of material properties, show a remarkable correlation with the record of natural orogenic belts. This holds for the overall structure as well as for the typical length scales and aspect ratios of the individual units, the time scales of metamorphism, the general shape of the $P-T$ paths, and the rate of subduction erosion. This suggests that the assumptions underlying the setup of the numerical experiment and the specific choice of parameters are not unrealistic. If so, the results lead to the following conclusions:

1. High-pressure metamorphic continental crust in orogenic belts need not necessarily be ascribed to the downgoing plate, but can be derived by subduction erosion from the active continental margin; hence, (U)HP metamorphism of continental material does not unequivocally indicate collision.

2. Large parts of the material removed by subduction erosion become wound up in a marble cake fashion in a broad wedge beneath the forearc, forming alternating nappes of lower and upper crustal provenience.

3. The kinematic patterns arising in our simulations suggest that in some aspects the paleogeographic reconstruction based on the vertical sequence of nappes in orogenic belts may need critical reevaluation.

4. Material carried further down into the subduction channel mixes with oceanic and hydrated mantle material and partly returns by forced flow. It is extruded on the landward side of the marble cake wedge, forming a megascale melange of HP and UHP nappes with contrasting $P-T$ paths.

5. A stable subduction channel with significant return flow appears to require a minimum rate of subduction. A Newtonian rheology favors fast and focused return flow in the subduction channel, compared to a power law rheology (Gerya and Stöckhert 2002).

6. The rate of return flow in the hanging wall of a subduction channel can exceed the rate of subduction and burial. Exhumation of (U)HP metamorphic rocks can proceed faster compared to the minimum uniform rate indicated by even narrow geochronological brackets.
7. Derivation of slices of continental crust by subduction erosion from the upper plate margin, and not from microcontinents in the downgoing plate, may resolve the problem of the discrepancy between the volume of continental crust required by paleogeographic reconstruction and the actual volume exposed in orogenic belts. In this case, there would be no need for the subduction of huge amounts of continental crust.

8. The internal nappe structure of an orogenic belt-like the Alps - may develop largely prior to collision, with overprint during collision being most important in the foremost forearc and in a region of backthrusting. For the Alps, such a pre-collisional mountain building process was previously discussed in much detail by Polino et al. (1990) and Spalla et al. (1996); their hypotheses are supported by the results of our simulations.

9. A final caveat: At real convergent margins, accessible in collisional orogenic belts like the Alps, the precollisional tectonometamorphic evolution studied in our simulations is probably strongly affected by crustal heterogeneity and may well be combined with episodic accretion of terranes (e.g., Ellis et al. 1999). The resulting complicated tectonometamorphic patterns are necessarily beyond the scope of our numerical simulation.

Acknowledgements Funding by the German Science Foundation within the scope of collaborative research center SFB 526 "Rheology of the Earth - from the upper crust into the subduction zone", by the Alexander von Humboldt Foundation, by the Russian Foundation of Basic Research (grant \# 03-05-64633), by the RF President Program "Leading Scientific School of Russia" (grant \# 03.5.1645), and by the ETH Research Grant TH-12/04-1 to T.V.G. is gratefully acknowledged. Careful reviews and helpful comments by S. Ellis, A. Babeyko, A. Pfiffner, and N. Kukowski are greatly appreciated. J. Connolly is thanked for checking the English.

\section{References}

Amato JM, Johnson CM, Baumgartner LP, Beard BL (1999) Rapid exhumation of the Zermatt-Saas ophiolite deduced from high-precision $\mathrm{Sm}-\mathrm{Nd}$ and $\mathrm{Rb}-\mathrm{Sr}$ geochronology. Earth Planet Sci Lett 171:425-438

Bai Q, Mackwell SJ, Kohlstedt DL (1991) High-temperature creep of olivine single crystals: 1: mechanical results of buffered samples. J Geophys Res 96:2441-2464

Beaumont C, Ellis S, Hamilton J, Fullsack P (1996) Mechanical model for subduction-collision tectonics of Alpine-type compressional orogens. Geology 24:675-678

Biino GG, Compagnoni R (1992) Very-high pressure metamorphism of the Brossasco coronite metagranite Southern DoraMaira-massif, Western Alps. Schweizerische Mineralogische und Petrographische Mitteilungen 72:347-363

Brace WF, Kohlestedt DL (1980) Limits on lithospheric stress imposed by laboratory experiments. J Geophys Res 85:6248-6252

Burg J-P, Gerya TV (2005) The role of viscous heating in Barrovian metamorphism of collisional orogens: thermomechanical models and application to the Lepontine Dome in the Central Alps. J Metamorph Geol 23:75-95 
Burov E, Jolivet L, Le Pourhiet L, Poliakov A (2001) A thermomechanical model of exhumation of high pressure (HP) and ultra-high pressure (UHP) metamorphic rocks in Alpine-type collision belts. Tectonophysics 342:113-136

Carswell DA, Zhang RY (1999) Petrographic characteristics and metamorphic evolution of ultrahigh-pressure eclogites in platecollision belts. Int Geol Rev 41:781-798

Cashman SM, Kelsey HM, Erdman CF, Cutten HNC, Berryman KR (1992) Strain partitioning between structural domains in the forearc of the Hikurangi Subduction Zone New Zealand. Tectonics 11:242-257

Cembrano J, Schermer E, Lavenu A, Sanhueza A (2000) Contrasting nature of deformation along an intra-arc shear zone the Liquine-Ofqui fault zone southern Chilean Andes. Tectonophysics 319:129-149

Chemenda AI, Mattauer M, Mattavieille J, Bokun AN (1995) A mechanism for syn-collisional rock exhumation and associated normal faulting: results from physical modelling. Earth Planet Sci Lett 132:225-232

Chopin C (2003) Ultrahigh pressure metamorphism: tracing continental crust into the mantle. Earth Planet Sci Lett 212:1-14

Chopra PN, Paterson MS (1981) The experimental deformation of dunite. Tectonophysics 78:453-473

Clauser C, Huenges E (1995) Thermal conductivity of rocks and minerals. In: Ahrens TJ (ed) Rock physics and phase relations, vol 3. American Geophysical Union Reference Shelf, Washington, DC, pp 105-126

Davies JH, von Blanckenburg F (1995) Slab breakoff: a model of lithospheric detachment and its test in the magmatism and deformation of collisional orogens. Earth Planet Sci Lett 129:85-102

Debelmas J, Escher A, Trümpy R (1983) Profiles through the western Alps. In: Rast N, Delaney MF (eds) Profiles of orogenic belts, vol. 10. American Geophysical Union Geodynamics Series, Washington, DC, pp 83-96

Duchêne S, Lardeaux J-M, Albarède F (1997) Exhumation of eclogites: insight from depth-time path analysis. Tectonophysics 280:125-140

Eide EA, Liou JG (2000) High-pressure blueschists and eclogites in Honǵan: a framework for addressing the evolution of high- and ultrahigh-pressure rocks in central China. Lithos 52:1-22

Ellis S, Beaumont C, Pfiffner OA (1999) Geodynamic models of crustal-scale episodic tectonic accretion and underplating in subduction zones. J Geophys Res 104:15169-15190

Ellis S, Wissing S, Pfiffner OA (2001) Strain localization as a key to reconciling experimentally derived flow-law data with dynamic models of continental collision. Int J Earth Sci 90:168-180

Ernst WG (1999) Metamorphism, partial preservation, and exhumation of ultrahigh-pressure belts. Island Arc 8:125-153

Ernst WG (2001) Subduction ultrahigh-pressure metamorphism and regurgitation of buoyant crustal slices-implications for arcs and continental growth. Phys Earth Planet Inter 127:253275

Escartin J, Hirth G (1997) Nondilatant brittle deformation of serpentinites: implications for Mohr-Coulomb theory and the strength of faults. J Geophys Res 102:2897-2913

Escartin J, Hirth G, Evans B (2001) Strength of slightly serpentinized peridotites: implications for the tectonics of oceanic lithosphere. Geology 29:1023-1026

Froitzheim N (2001) Origin of the Monte Rosa Nappe in the Pennine Alps - a new working hypothesis. Geol Soc Am Bull 113:604-614

Froitzheim N, Schmid SM, Frey M (1996) Mesozoic paleogeography and the timing of eclogite-facies metamorphism in the Alps: a working hypothesis. Eclogae Geol Helv 89:81-110

Gebauer D, Schertl HP, Brix M, Schreyer W (1997) 35 Ma old ultrahigh-pressure metamorphism and evidence for very rapid exhumation in the Dora Maira Massif, Western Alps. Lithos 41:5-24

Gerya TV, Stöckhert B (2002) Exhumation rates of high pressure metamorphic rocks in subduction channels: the effect of rheology. Geophys Res Lett 29:102-1-102-4
Gerya TV, Yuen DA (2003a) Rayleigh-Taylor instabilities from hydration and melting propel "cold plumes" at subduction zones. Earth Planet Sci Lett 212:47-62

Gerya TV, Yuen DA (2003b) Characteristics-based marker-in-cell method with conservative finite-differences schemes for modeling geological flows with strongly variable transport properties. Phys Earth Planet Int 140:295-320

Gerya TV, Perchuk LL, van Reenen DD, Smit CA (2000) Twodimensional numerical modeling of pressure-temperature-time paths for the exhumation of some granulite facies terrains in the Precambrian. J Geodyn 30:17-35

Gerya TV, Stöckhert B, Perchuk AL (2002) Exhumation of highpressure metamorphic rocks in a subduction channel-a numerical simulation. Tectonics 21:6-1-6-19

Gerya TV, Yuen DA, Sevre EOD (2004) Dynamical causes for incipient magma chambers above slabs. Geology 32:89-92

Grawinkel A, Stöckhert B (1997) Hydrostatic pore fluid pressure to $9 \mathrm{~km}$ depth-fluid inclusion evidence from the KTB deep drill hole. Geophys Res Lett 24:3273-3276

Guillot S, Hattori KH, de Sigoyer J (2000) Mantle wedge serpentinization and exhumation of eclogites: insight from eastern Ladakh northwest Himalaya. Geology 28:199-202

Hacker BR (1996) Eclogite formation and the rheology, buoyancy, seismicity, and $\mathrm{H} 2 \mathrm{O}$ content of oceanic crust. In: Bebout GE, Scholl DW, Kirby SH, Platt JP (eds) Subduction top to bottom. AGU Monogr pp 337-346

Hacker BR, Liou JG (1998) When continents collide: geodynamics and geochemistry of ultrahigh-pressure rocks. Kluwer Academic, Dordrecht

Hermann J, Muntener O, Scambelluri M (2000) The importance of serpentinite mylonites for subduction and exhumation of oceanic crust. Tectonophysics 327:225-238

Huenges E, Erzinger J, Kuck J, Engeser B, Kessels W (1997) The permeable crust: geohydraulic properties down to $9,101 \mathrm{~m}$ depth. J Geophys Res 102:18255-18265

Kirby SH, Engdahl ER, Denlinger R (1996) Intermediate-depth intraslab earthquakes and arc volcanism as physical expressions of crustal and uppermost mantle metamorphism in subducting slabs. In: Bebout GE, Scholl DW, Kirby SH, Platt JP (eds) Subduction top to bottom. Geophys Monogr 96:195214

Kurz W, Froitzheim N (2002) The exhumation of eclogite-facies metamorphic rocks - a review of models confronted with examples from the Alps. Int Geol Rev 44:702-743

Mackwell SJ, Zimmerman ME, Kohlstedt DL (1998) High-temperature deformation of dry diabase with application to tectonics on Venus. J Geophys Res 103:975-984

Mauler A, Godard G, Kunze K (2001) Crystallographic fabrics of omphacite, rutile, and quartz in Vendée eclogites (Armorican Massif France): consequences for deformation mechanisms and regimes. Tectonophysics 342:81-112

Mei S, Kohlstedt DL (2000) Influence of water on plastic deformation of olivine aggregates. 2: Dislocation creep regime. J Geophys Res 105:21471-21481

Meier T, Rische M, Endrun B, Vafidis A, Harjes H-P (2004) Seismicity of the Hellenic Subduction Zone in the area of western and central Crete observed by temporary local seismic networks. Tectonophysics 383:149-169

Moore DE, Lockner AD, Shengli M, Summers R, Byerlee JD (1997) Strengths of serpentinite gouges at elevated temperatures. J Geophys Res 102:14787-14801

Oncken O, Sobolev S, Stiller M, Lüschen E, et al (ANCORP Working Group) (2003) Seismic imaging of an active continental margin - the central Andes (ANCORP '96). J Geophys Res 108 (doi:10 1029/2002JB001771)

Paterson MS (1987) Problems in the extrapolation of laboratory rheological data. Tectonophysics 133:33-43

Paterson MS, Luan FC (1990) Quartzite rheology under geological conditions. In: Knipe RJ, Rutter EH (eds) Deformation mechanisms, rheology, and tectonics. Geol Soc Lond Spec Publ 54:299-307 
Peacock SM (1987) Serpentinization and infiltration metasomatism in the Trinity peridotite, Klamath province, northern California: implications for subduction zones. Contrib Mineral Petrol 95:55-70

Peacock SM (1996) Thermal and petrologic structure of subduction zones. In: Bebout GE, Scholl DW, Kirby SH, Platt JP (eds) Subduction top to bottom. Geophys Monogr 96:119-133

Pfiffner OA, Frei W, Valasek P, Stäuble M, Levato L, DuBois L, Schmid SM, Smithson SB (1990) Crustal shortening in the Alpine orogen: results from deep seismic reflection profiling in the estern Swiss Alps Line NFP 20-EAST. Tectonics 9:1327-1355

Pfiffner OA, Lehner P, Heitzmann P, Mueller S, Steck A (eds) (1997) Deep structure of the Swiss Alps. Results from NRP 20. Birkhäuser, Basel, p 380

Pfiffner OA, Ellis S, Beaumont C (2000) Collision tectonics in the Swiss Alps: insight from geodynamic modelling. Tectonics 19:1065-1094

Poli S, Schmidt MW (2002) Petrology of subducted slabs. Annu Rev Earth Planet Sci 30:207-235

Poliakov ANB, van Balen R, Podladchikov Y, Daudre B, Cloetingh $\mathrm{S}$, Talbot C (1993) Numerical analysis of how sedimentation and redistribution of surficial sediments affects salt diapirism. Tectonophysics 226:199-216

Polino R, Dal Piaz GV, Gosso G (1990) Tectonic erosion at the Adria margin and accretionary processes for the Cretaceous orogeny of the Alps. Mem Soc Geol Fr 156:345-367

Ranalli G (1995) Rheology of the Earth. Chapman and Hall, London, p 413

Reinecke T (1998) Prograde high- to ultrahigh-pressure metamorphism and exhumation of oceanic sediments at Lago di Cignana, Zermatt-Saas Zone, western Alps. Lithos 42:147-189

Renner J, Stöckhert B, Zerbian A, Röller K, Rummel F (2001) An experimental study into the rheology of synthetic polycrystalline coesite aggregates. J Geophys Res 106:19411-19429

Rubatto D, Hermann J (2001) Exhumation as fast as subduction. Geology 29:3-6

Scambelluri M, Philippot P (2001) Deep fluids in subduction zones. Lithos 55:213-227

Schertl H-P, Schreyer W, Chopin C (1991) The pyrope-coesite rocks and their country rocks at Parigi, Dora Maira massif, western Alps: detailed petrography, mineral chemistry, and P-T path. Contrib Mineral Petrol 108:1-21

Schmid SM, Pfiffner OA, Froitzheim N, Schönborn G, Kissling E (1996) Geophysical-geological transect and tectonic evolution of the Swiss-Italian Alps. Tectonics 15:1036-1064

Schmid SM, Fügenschuh B, Kissling E, Schuster R (2004) Tectonic map and overall architecture of the Alpine orogen. Ecol Geol Helv 97:93-117

Schmidt MW, Poli S (1998) Experimentally based water budgets for dehydrating slabs and consequences for arc magma generation. Earth Planet Sci Lett 163:361-379
Schott B, Schmeling H (1998) Delamination and detachment of a lithospheric root. Tectonophysics 296:225-247

Sibson RH (1990) Faulting and fluid flow. In: Nesbitt BE (ed) Fluids in tectonically active regimes of the continental crust. Mineral Association of Canada Short Course, pp 92-132

Spalla MI, Lardeaux J-M, Dal Piaz GV, Gosso G, Messiga B (1996) Tectonic significance of Alpine eclogites. J Geodyn 21:257-285

Stampfli GM, Moser J, Marquer D, Marchant R, Baudin T, Morel G (1998) Subduction and obduction processes in the Swiss Alps. Tectonophysics 296:159-204

Stöckhert B (2002) Stress and deformation in subduction zone$\mathrm{s}$ - insight from the record of exhumed high pressure metamorphic rocks. In: de Meer S, Drury M, de Bresser H, Pennock $G$ (eds )Deformation mechanisms, rheology and tectonics: current status and future perspectives. Geol Soc Lond Spec Publ 200:255-274

Stöckhert B, Gerya TV (2005) Pre-collisional high pressure metamorphism and nappe tectonics at active continental margins: a numerical simulation. Terra Nova 17(2):102-110

Stöckhert B, Renner J (1998) Rheology of crustal rocks at ultrahigh-pressure. In: Hacker BR, Liou JG (eds) When continents collide: geodynamics and geochemistry of ultrahigh-pressure rocks. Kluwer Academic, Dordrecht, pp 57-95

Stöckhert B, Wachmann M, Küster M, Bimmermann S (1999) Low effective viscosity during high pressure metamorphism due to dissolution precipitation creep: the record of HP-LT metamorphic carbonates and siliciclastic rocks from Crete. Tectonophysics 303:299-319

Stöckhert B, Duyster J, Trepmann C, Massonne H-J (2001) Microdiamond daughter crystals precipitated from supercritical $\mathrm{COH}$ silicate fluids included in garnet, Erzgebirge, Germany. Geology 29:391-394

Turcotte DL, Schubert G (1982) Geodynamics: applications of continuum physics to geological problems. Wiley, New York, NY, p 450

von Blanckenburg F, Davies JH (1995) Slab breakoff: a model for syncollisional magmatism and tectonics in the Alps. Tectonics $14: 120-131$

von Huene R, Scholl DW (1991) Observations at convergent margins concerning sediment subduction, subduction erosion, and the growth of continental crust. Rev Geophys 29:279-316

Yuan X, Sobolev SV, Kind R, Oncken O, Bock G, Asch G, Schurr B, Graeber F, Rudloff A, Hanka W, Wylegalla K, Tibi R, Haberland C, Rietbrock A, Giese P, Wigger P, Rower P, Zandt G, Beck S, Wallace T, Pardo M, Comte D (2000) Subduction and collision processes in the Central Andes constrained by converted seismic phases. Nature 408:958-961

Zimmermann R, Hammerschmidt K, Franz G (1994) Eocene high pressure metamorphism in the Penninic units of the Tauern Window (Eastern Alps): evidence from 40Ar-39Ar dating and petrologic investigations. Contrib Mineral Petrol 117:175-186 